\title{
Diálogos entre a pintura e o cinema: análise de representações pictóricas do relato de Susana e os velhos e de sua aparição em Psicose, de Alfred Hitchcock
}

\section{Vanessa Brasil Campos Rodríguez}

Doutora; Universidade Salvador, Salvador, BA, Brasil

vanessabrasil.rodriguez@gmail.com

\section{Resumo}

O artigo é resultado de investigação sobre o filme Psicose, de Alfred Hitchcock, de 1960. O tema do quadro que tapa o buraco pelo qual o protagonista Norman Bates observa Marion Crane despindo-se constitui o elemento de análise. Trata-se de uma representação do relato bíblico de Susana e os velhos que aborda o voyeurismo, o desejo incestuoso de dois juízes e a violação. $O$ trabalho abrange a pesquisa semiótica em interface com a psicanálise, a antropologia e a comunicação na cultura. 0 método abordado é a análise do discurso fílmico e pictórico. Assinalam-se as ressonâncias formais, estéticas e estruturais entre as pinturas e o filme. As imagens analisadas em Psicose apresentam camadas extremamente profundas e arraigadas a elementos imagéticos, localizadas em várias pinturas do século XVII que abordam o tema de Susana e os velhos. Estas sobreviveram e transportaram-se através do tempo, do espaço e entre culturas..

\section{Palavras-chave}

Análise do discurso. Cinema. Alfred Hitchcock. Susana e os velhos. Voyeurismo.

\section{Introdução}

0 artigo surgiu de uma indagação sobre um dos momentos mais significativos do filme Psicose (1960a), de Alfred Hitchcock, quando Norman (Anthony Perkins), após sua conversa com Marion Crane (Vera Miles), na sala dos pássaros empalhados do Motel Bates, 
Diálogos entre a pintura e o cinema: análise de representações pictóricas do relato de Susana e os velhos e de sua aparição em Psicose,

vai em direção a uma parede com alguns quadros e remove um deles. Nesse momento, surge um grande buraco de bordas irregulares (Figura 3) por onde ele a espia.

0 quadro apresenta uma pintura que mostra três personagens em determinada ação (Figura 2): dois anciãos tentam agarrar uma moça nua que protege seu sexo com um manto que um dos velhos tenta arrancar. A mulher levanta a mão direita em sinal de repúdio ao ataque. 0 cenário está repleto de árvores, e há uma fonte com uma escultura esboçada, ao fundo, sugerindo um jardim. 0 quadro funciona como um esconderijo, para tapar um imenso rombo irregular, que abriga outro buraco interior e que permite a Norman visualizar o corpo nu de Marion. Ela, por sua vez, se prepara para o banho no quarto número um do Bates Motel. Esse quadro constitui um ponto de interrogação no filme, atua como um enigma a ser desvendado e, por isto, merece uma investigação mais prolongada: que representação é essa e a qual relato se refere? Por que foi justamente esta imagem a escolhida para tapar o buraco e por que está aí? Qual o seu significado?

Os objetivos do trabalho são: desvendar a imagem contida no quadro, ou seja, identificar a que relato se refere; investigar representações com a mesma temática na pintura e ver os pontos de interseção entre as obras; analisar os elementos mais significativos em cada representação e em sua relação com o filme Psicose; dialogar a obra com a cena do chuveiro, na qual Marion Crane é assassinada. A proposta do artigo é, em suma, fazer a análise do relato a partir de representações selecionadas do tema em questão e buscar os diálogos com o filme de Hitchcock.

Figura 1 - Norman retirando o quadro da parede

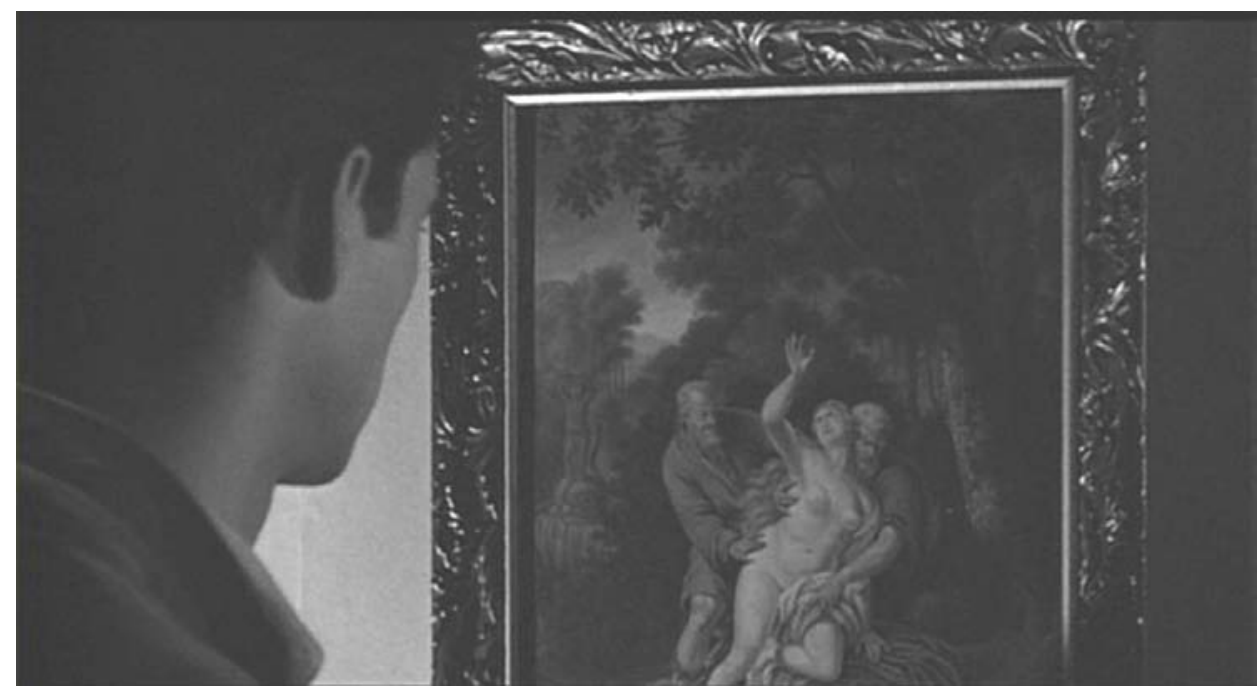

Fonte: Fotograma capturado pela autora, adaptado de Psicose (1960a). 
Diálogos entre a pintura e o cinema: análise de representações pictóricas do relato de Susana e os velhos e de sua aparição em Psicose,

Figura 2 - Susana e os velhos, de Van Mieris Frans, o velho

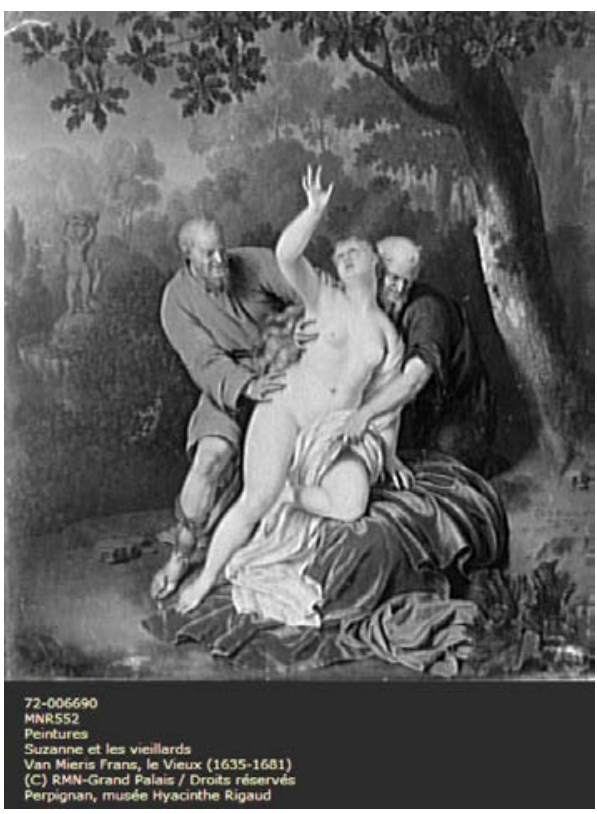

Fonte: Adaptado de Mieris (16--?). Registro do Musée Hyacinthe Rigaud, Perpignan, de 1957.

Figura 3 - Norman diante do buraco na parede, e espiando atrás dele
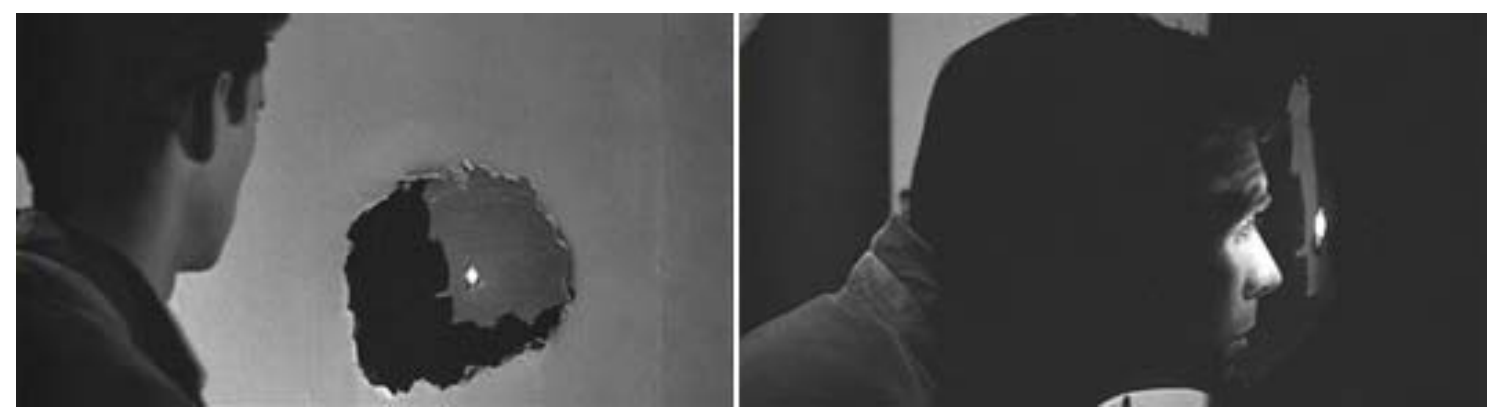

Fonte: Fotograma capturado pela autora, adaptado de Psicose (1960a).

\section{Metodologia}

A metodologia abordada de análise do discurso define-se como "leitura". No modelo de leitura proposto por González Requena (1995, 1996), intitulado Teoria do texto, o analista começa seu trabalho penetrando através dos significantes do texto (pictórico, fílmico, teatral, etc). Partiu-se dos significantes, em busca dos significados em seus múltiplos encadeamentos. Deste modo, entra-se em contato com certos elementos fortes que, ao entrecruzarem-se, definem o tecido textual, a textura. A leitura possibilita uma experiência de encontro com uma rede simbólica, visto que está tecida com símbolos que ressoam no 
sujeito, no único sujeito possível: o que está diante do texto, o que o lê - no caso do espectador. Então, empreende-se o caminho da análise. Essa é uma atividade de reconhecimento do texto. A semiótica define "texto" como a realização das virtualidades do sistema da língua ou de um código dado. González Requena $(1995,1996)$ avança na proposta semiótica e na teoria barthesiana e sugere uma nova concepção de texto. Nesse sentido, ele passa a ser uma estrutura dinâmica, com articulação, ritmo e estrutura. Da mesma forma que o objeto a ser analisado transforma-se em texto, a partir do momento em que prestamos atenção aos múltiplos encadeamentos de seus significantes e jogos de sentido potenciais que só se realizam quando iniciamos a leitura, o texto só se desdobra no processo de análise. Isso é a leitura: a definição de um volume, de sentidos múltiplos que nascem das muitas travessias operadas através dos significantes do texto. Múltiplas travessias que, ao entrelaçarem-se nesses elementos fortes que encontramos quando analisamos os textos, definem a rede, o tecido textual (GONZÁLEZ REQUENA, 1985). Em outras palavras, fazemos leitura ao pé da letra. Nossa proposta de análise, apoia-se também em Trías:

\begin{abstract}
Trata-se de contemplar sempre o avesso do tapete, as costuras e as laçadas que possibilitam a firmeza do mesmo, ou sua proliferação de cenas vivas e animadas. Trata-se de situar-se sempre no limite entre este "esplendor" de vivacidade e de relato e a face oculta, ou sombria, que normalmente fica de fora da representação. (TRÍAS, 2006, p. 18, tradução nossa).
\end{abstract}

É no lado avesso do tapete que encontram-se os nós, as costuras, o tecido costurado e as linhas cruzadas. Interessamo-nos por este lado que está sempre oculto, mas que, uma vez descoberto, é sempre revelador.

O trabalho abrange a pesquisa semiótica na sua interface com a comunicação na cultura. As disciplinas teóricas que guiam a análise são a semiótica narrativa, a antropologia, a psicanálise e a teoria do texto. A antropologia visual propõe não somente olhar as imagens, mas também perceber o caráter cultural, implícito ou subjetivo e, assim, lê-las como textos. Segundo Samain (2011), deve-se considerar a relevância e a possibilidade de constituição de um diálogo entre áreas afins, como a arte, a antropologia e as imagens, para que haja um entendimento da cultura. Para o autor "[...] é urgente recolocar a arte no epicentro da existência humana, isto é, no centro da cultura, de todas as culturas [...]" (SAMAIN, 2011, p. 31). 
A psicanálise dá o suporte necessário para abordar uma teoria da linguagem em relação direta com a constituição da subjetividade humana. A semiótica narrativa permitirá uma formalização da análise, que trataremos de transcender a uma teoria do relato. Calabrese (1997), por usa vez, desenha uma função específica para a semiótica aplicada ao campo da arte, como a pintura figurativa. 0 autor esclarece que disciplinas mais abstratas como a semiótica "[...] têm a possibilidade de analisar objetos figurativos como objetos teóricos, dotados de meios metalinguísticos próprios e específicos.” (CALABRESE, 1997, p. 37).

Calabrese (1997) mostra a importância da intertextualidade na leitura de obras de arte: “[...] exatamente a da referência a textos que não estão expressos na própria matéria da expressão do texto inicial." (CALABRESE, 1997, p. 40). O autor explica que intertexto é um conjunto de propriedades mais ou menos genéricas de outros textos evocados pela obra, admintindo-se que essas propriedades correspondem a textos de qualquer tipo. Desta forma, um quadro remete a um filme ou a uma obra literária.

Manguel (2001) cita o ministro da cultura da França, André Malraux, para argumentar que:

[...] ao situarmos uma obra de arte entre as obras de arte antes e depois dela, nós, os espectadores modernos, tornávamo-nos os primeiros a ouvir aquilo que ele [Malraux] chamou de "canto da metamorfose" - quer dizer, o diálogo que uma pintura ou uma escultura trava com outras pinturas e esculturas, de outras culturas e de outros tempos. (MANGUEL, 2001, p. 2728).

É importante nesse estudo fazer tal diálogo, estabelecendo as interseções e os cruzamentos entre as obras, para, finalmente, poder articular algo que tenha sentido para o sujeito, o leitor e o espectador. Baseamo-nos, também, em um das máximas do historiador de arte Warburg, de que as obras de arte são as "[...] vias de acesso para a compreensão de certas sutilezas da cultura [...]" (TEIXEIRA, 2010, p. 139). Warburg (20091 apud TEIXEIRA, 2010) utilizou-se das várias possibilidades do estudo da imagem para comprovar sua tese: de que existem elementos nas representações imagéticas que sobrevivem ao tempo e que conseguem permanecer presentes em diversos períodos da história. Warburg (19902 apud

\footnotetext{
1 WARBURG, Aby. “Mnemosyne”. Arte \& Ensaios, Rio de Janeiro, n. 19, p. 30-51, 2009. Apud Teixeira (2010).

2 WARBURG, Aby. L'art du portrait et la bourgeoisie florentine. Essais florentins. Paris: Klincksieck, 1990. Apud Teixeira (2010).
} 
TEIXEIRA, 2010) criou o conceito de Pathosformel (fórmulas de páthos), um repertório de formas de expressar o movimento e as paixões desenvolvidas pelos artistas antigos, passadas adiante por meio das obras de arte, apropriadas no Renascimento e, ainda, como classificação das fórmulas usadas na tradição figurativa europeia operada pelos historiadores da arte (SETTIS, $2004^{3}$ apud TEIXEIRA, 2010).

Michaud (2013), seguindo a teoria de Warburg, diz que a imagem, apesar de ser um elemento repleto de interferências que se ateram dependendo do tempo ou espaço ao qual pertence, consegue manter certas ligações - objetivas ou subjetivas - com outras imagens ou interferências. Segundo o autor, “[...] a imagem não é um campo de um saber fechado. É um campo turbilhonante e centrífugo. [...] É um movimento que requer todas as dimensões antropológicas do ser e do tempo[...]" (MICHAUD, 2013, p. 21). Neste sentido, foi fundamental a compreensão desta amplitude do pensamento warburguiano, a fim de estabelecer as conexões e os diálogos entre o cinema e a pintura, em especial, o momento fílmico de Psicose e as obras de arte que abordam o mesmo tema da cena que nos convoca.

0 primeiro passo da pesquisa foi investigar a origem da cópia da pintura que aparece no filme Psicose na cena do buraco e o seu autor. Primeiramente, foi possível identificar o tema da pintura. Trata-se de uma representação de Susana e os velhos, uma história da Bíblia. Após quatro anos de busca, finalmente, em 2016, foi possível encontrar referências à obra, seu autor e sua localização anterior. Trata-se de um quadro do pintor holandês Frans Van Mieris, o velho, e pertencia aos acervos do Musée Hyacinthe Rigaud, em Perpingnan (França), conforme registro do museu (Figura 2). Contudo, em 21 de julho de 1972, a obra foi roubada e jamais recuperada. Tal fato aumenta ainda mais o mistério e o enigma que a cercam. Van Mieris poderia tê-la pintado por volta de 1650, segundo dados do Museu Hyacinthe Rigaud. Isso corresponde às pesquisas feitas para o estudo, pois suas características estéticas podem indicá-la como pertencente ao século XVII, época em que o tema de Susana e os velhos foi bastante explorado na pintura por artistas de renome. Neste sentido, na ausência do original em cores, concentramo-nos em outras obras consagradas desse período, a fim de estabelecer o diálogo com a obra presente no filme. Concentramonos, ainda, para efeitos de recorte da pesquisa, nas obras de Susana registradas pelo respeitado site internacional de catalogação de obras de arte históricas, Web Gallery of Art

\footnotetext{
${ }^{3}$ SETTIS, Salvatore. Pathos ed ethos, morfologia e funzione. Moderna. Semestrale di Teoria e Critica della Letteratura Roma, v. 6 , n. 2, p. 23-34, 2004. Apud Teixeira (2010).
} 
Diálogos entre a pintura e o cinema: análise de representações pictóricas do relato de Susana e os velhos e de sua aparição em Psicose,

(1996). A busca resultou na emergência de obras significativas, nas quais nos apoiaremos nessa pesquisa.

\section{Análise dos resultados: cruzamentos entre o relato de Susana nas pinturas e no filme Psicose}

O quadro escolhido por Hitchcock para tapar o grande buraco que circunda outro menor, através do qual Norman Bates observa Marion é uma representação do conto bíblico de Susana e os velhos (Figura 1 e Figura 2). A obra é muito significativa, e o próprio Hitchcock (PSICOSE, 1960b), no trailer do filme, ressalta-o, apontando com o dedo: "Este quadro tem uma grande significação, porque [...]" (Figura 4) e, sem concluir a frase, convida o espectador a dirigir-se ao quarto número um. A frase inconclusa já havia convocado o espectador muito antes da estreia do filme.

Figura 4 - Hitchcock aponta para o quadro no trailer de Psicose

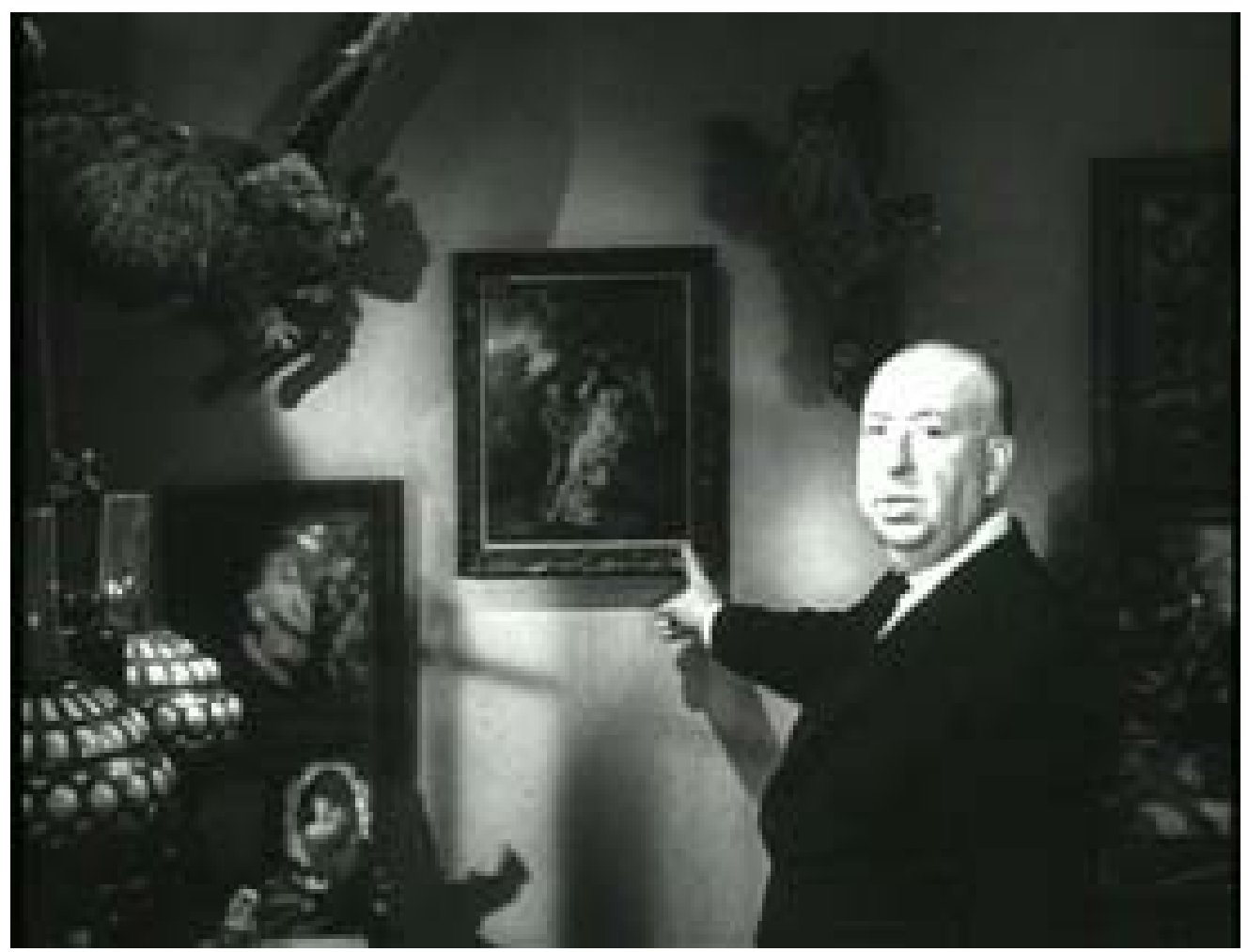

Fonte: Fotograma capturado pela autora, adaptado de Psicose (1960b).

Após retirar o quadro, Norman Bates observa pelo orifício na parede. Um grande plano detalhe mostra um olho à esquerda do enquadramento em oposição a um buraco 
Diálogos entre a pintura e o cinema: análise de representações pictóricas do relato de Susana e os velhos e de sua aparição em Psicose,

rasgado na parede, à direita. Sua potência é avassaladora (Figura 5). Como uma esfinge, o fotograma formula um enigma visual. 0 que deseja? Até onde vai este olhar?

Figura 5 - Norman observando pelo buraco na parede e Marion despindo-se e sendo observada por ele
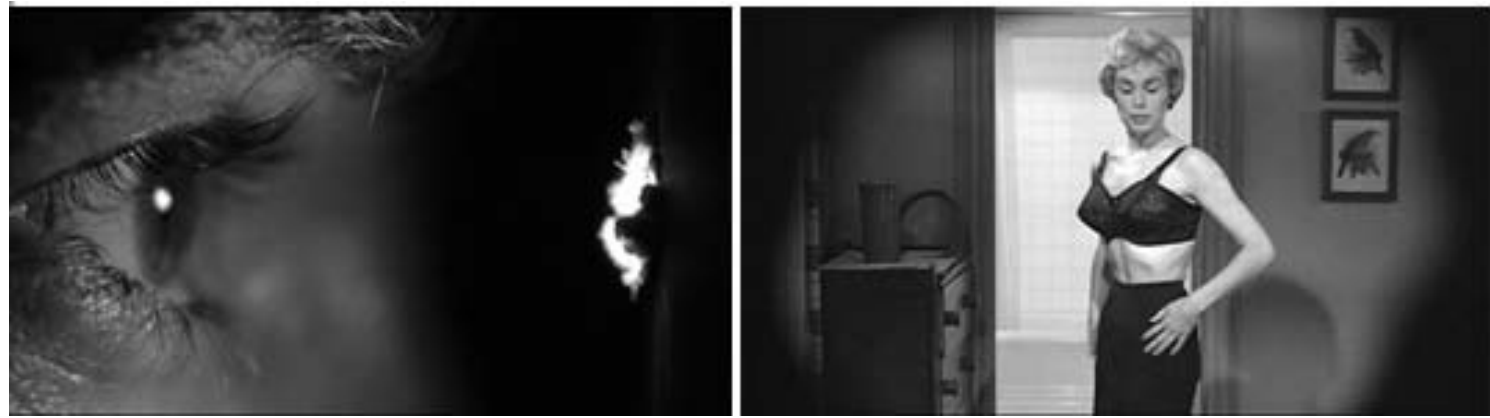

Fonte: Fotograma capturado pela autora, adaptado de Psicose (1960b).

O superclose do globo ocular em perfil aparece ocupando metade da tela, enorme e devorador. Esse imenso olho famélico que brilha sobre o fundo negro absorve a figura de Marion se despindo (Figura 5). Essa imagem emblemática é, sem dúvida, a melhor metáfora plástica da pulsão escópica.

O conceito de pulsão escópica permitiu à psicanálise restabelecer uma função de atividade para o olho não mais como fonte de visão, mas como fonte de libido. Onde os antigos têm o conceito de raio visual e o fogo do olhar, a psicanálise descobre a libido de ver e o objeto olhar como manifestação da vida sexual. Lá onde estava a visão, Freud descobre a pulsão. (QUINET, 2002, p. 10).

Esse plano sintetiza, também, a fusão da mirada do espectador com a do personagem, reduzido à posição de voyeur. Quando Norman espia pelo buraco da parede, o espectador vê a si mesmo olhando e, por sua vez, vê-se sendo observado, já que, no âmbito do contraplano, nos identificamos com essa mulher ameaçada. Hitchcock mostra, nessa cena antológica, a obsessão e o risco de olhar para além do que pode ser visto. Coloca lado a lado o ato de observar e o de ser corpo que atrai os olhares.

0 grande plano detalhe do olho de Norman observando Marion, que se desnuda para banhar-se, transforma essa mulher em vítima de uma violação visual (Figura 5). Quinet (2002, p. 12) adverte: “[...] o olhar é o objeto da angústia quando a pulsão escópica se revela como pulsão de morte: o olhar é portador de um gozo mortífero [...]". 
Diálogos entre a pintura e o cinema: análise de representações pictóricas do relato de Susana e os velhos e de sua aparição em Psicose,

Marion já havia sido profanada em outro âmbito, quando a voz da senhora Bates penetra pela janela do quarto da moça, ferindo com palavras ácidas a sua honra. Aqui, nesta sequência, ela é violada visualmente, pelos olhos de Norman ou pelo olhar do espectador (Figuras 5). 0 tema do quadro que tapa o buraco rima perfeitamente com o olhar de Norman que atravessa a parede e invade o espaço da mulher, rapinando-a antes de abatê-la, como os velhos fizeram com a Susana bíblica.

0 relato de Susana e os velhos é um dos textos mais fascinantes do Livro de Daniel, presente na Bíblia. Conta a história de uma mulher muito bela, esposa de Joaquim, um influente judeu exilado na Babilônia. Dois velhos que haviam sido nomeados juízes entre os judeus iam diariamente à mansão de Joaquim para aconselhar aos que necessitassem. A beleza de Susana atraiu a atenção dos homens da lei, que começaram a observá-la em segredo quando a mulher saía para dar um passeio diário pelo seu jardim. Pouco a pouco vai crescendo a cobiça e a lascívia no ânimo dos juízes (Figura 6).

Figura 6 - Susana e os velhos, de Jan Both, 1642

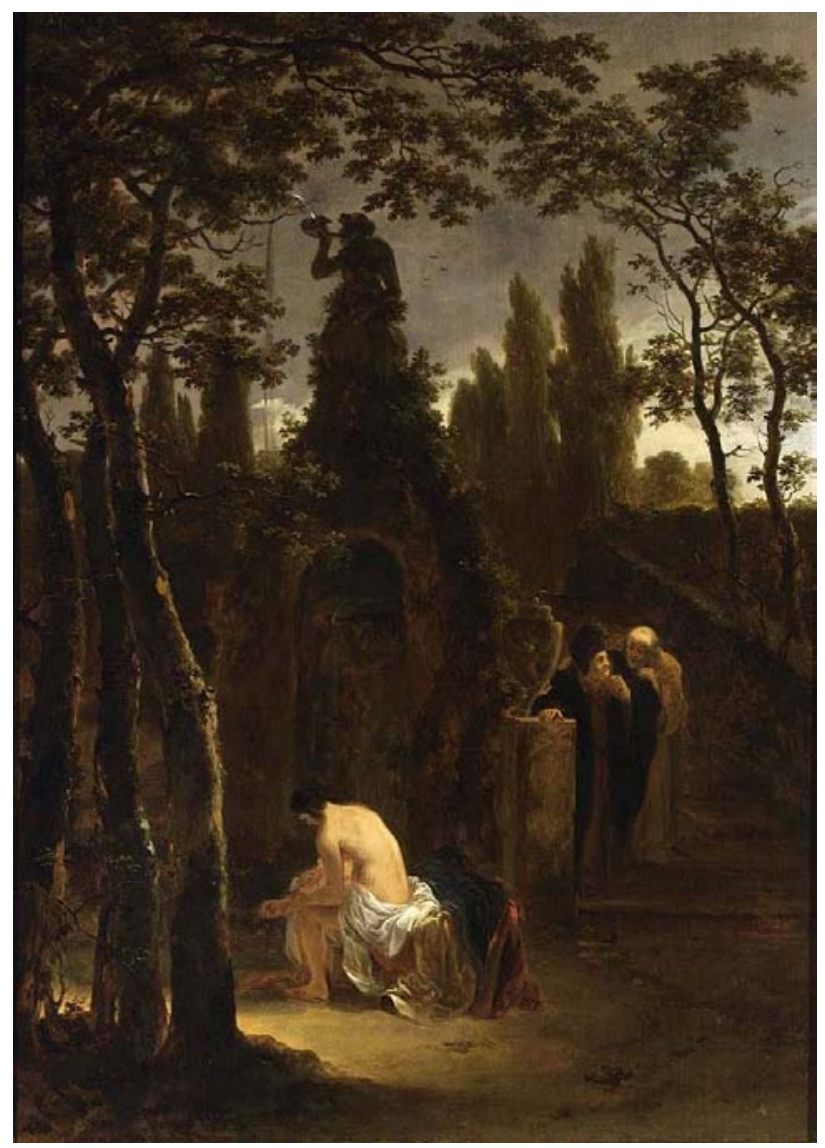

Fonte: Both (1642). 
Diálogos entre a pintura e o cinema: análise de representações pictóricas do relato de Susana e os velhos e de sua aparição em Psicose,

Os velhos escondidos espreitavam, esperando ansiosamente a hora do passeio de Susana. Todos os dias espiavam a bela mulher nos seus momentos de recolhimento. Por fim, os dois se puseram de acordo para surpreender a esposa de Joaquim e violentá-la (Figura 7).

Figura 7 - Susana e os velhos, de Guercino, 1617

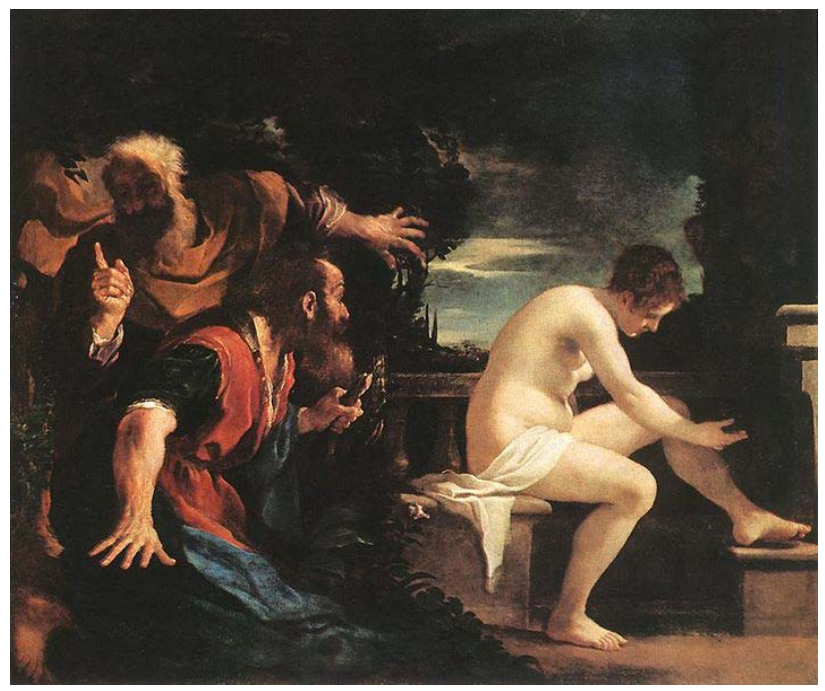

Fonte: Guercino (1617).

Em um dia de calor, Susana passeava pelo seu pomar e pediu às criadas que fechassem os portões do palácio porque iria banhar-se na fonte. De repente, os velhos juízes a surpreendem, agarram a mulher e tentam violá-la. Susana os repudia e chorando aos gritos, solicita a intervenção divina (Figura 8).

Figura 8 - Susana e os velhos, de Gerrit van Honthorst, ca. 1600

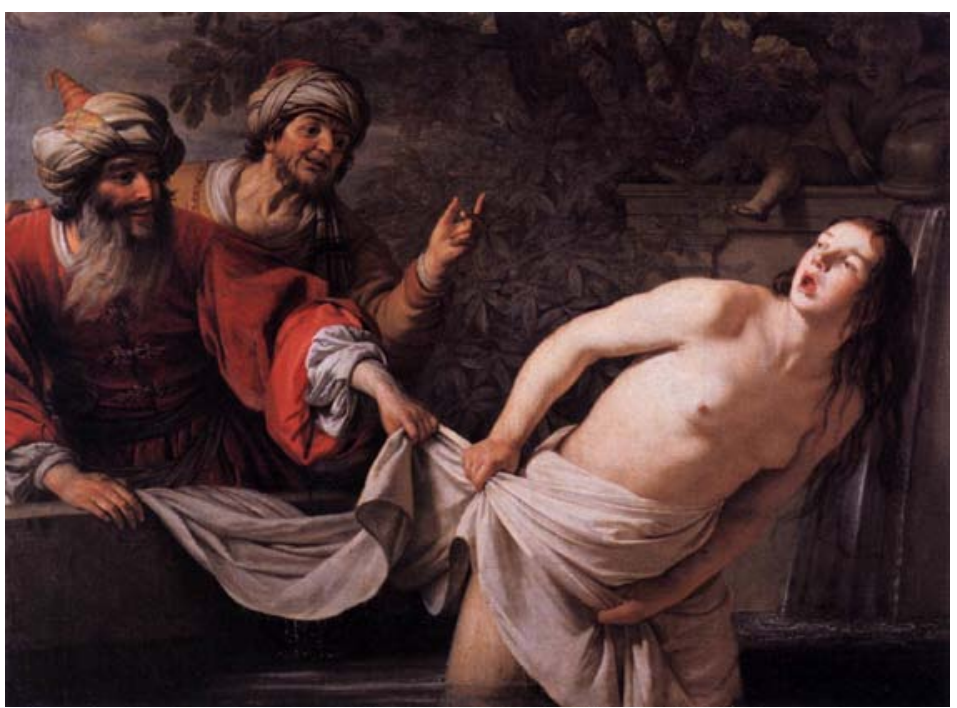

Fonte: Honthorst (16--?). 
Diálogos entre a pintura e o cinema: análise de representações pictóricas do relato de Susana e os velhos e de sua aparição em Psicose,

Os dos anciãos, ao se verem rechaçados, acusam Susana de adultério. Caluniam a esposa de Joaquim, dizendo que a viram com um rapaz debaixo de certa árvore.

Susana, etimologicamente, é quem possui a graça do lírio branco, alva e pura ${ }^{4}$. Ela representa, nesse relato, não a pureza das virgens, mas a honra das esposas fiéis. É portadora da fidelidade daquelas que cumprem com a palavra dada. Sua beleza incorrupta atrai o olhar dos homens sombrios, dos corruptos, dos falsos representantes da lei (Figura 9).

Figura 9 - Susana e os velhos, de Sisto Badalocchio, 1609

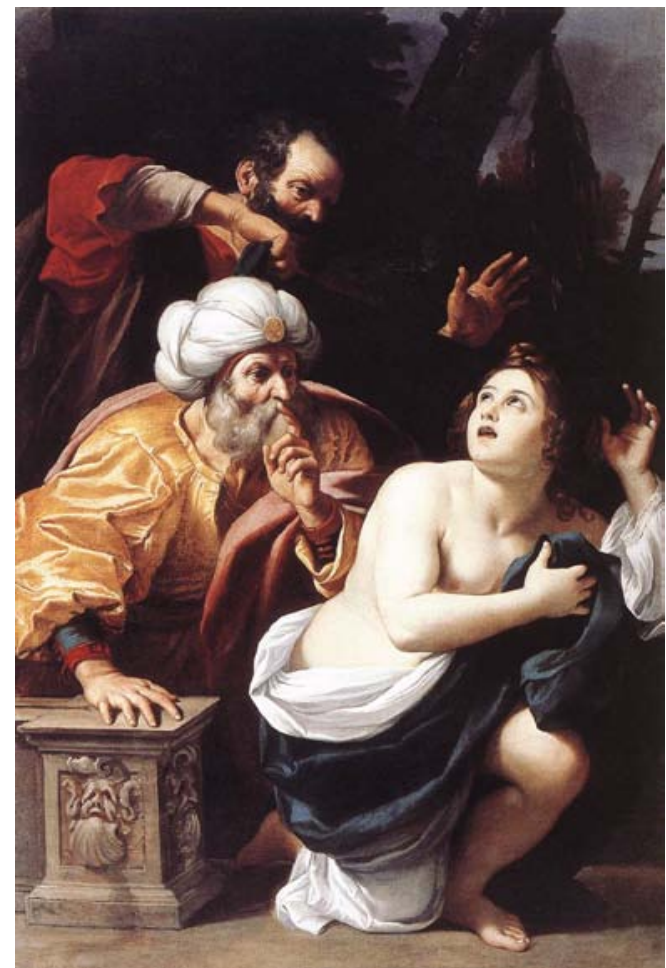

Fonte: Badalocchio (1609).

O prazer de espiar, de vigiar, de atravessar o corpo branco da mulher com o olhar de rapina constituirão temas atraentes para a arte. Nada protege o corpo de Susana da mirada dos juízes, nem os portões fechados, nem os umbrais ou cercas de seu jardim, não há limites que impeçam o avance escópico (Figura 10).

\footnotetext{
${ }^{4} 0$ nome Susana vem do hebreu shushannah, de shus, "açucena, lírio branco", e hannah, "graça". Desta forma, o significado de Susana é um lírio ou açucena graciosa.
} 
Diálogos entre a pintura e o cinema: análise de representações pictóricas do relato de Susana e os velhos e de sua aparição em Psicose, de Alfred Hitchcock

Figura 10 - Susana e os velhos, de Rembrandt, 1647

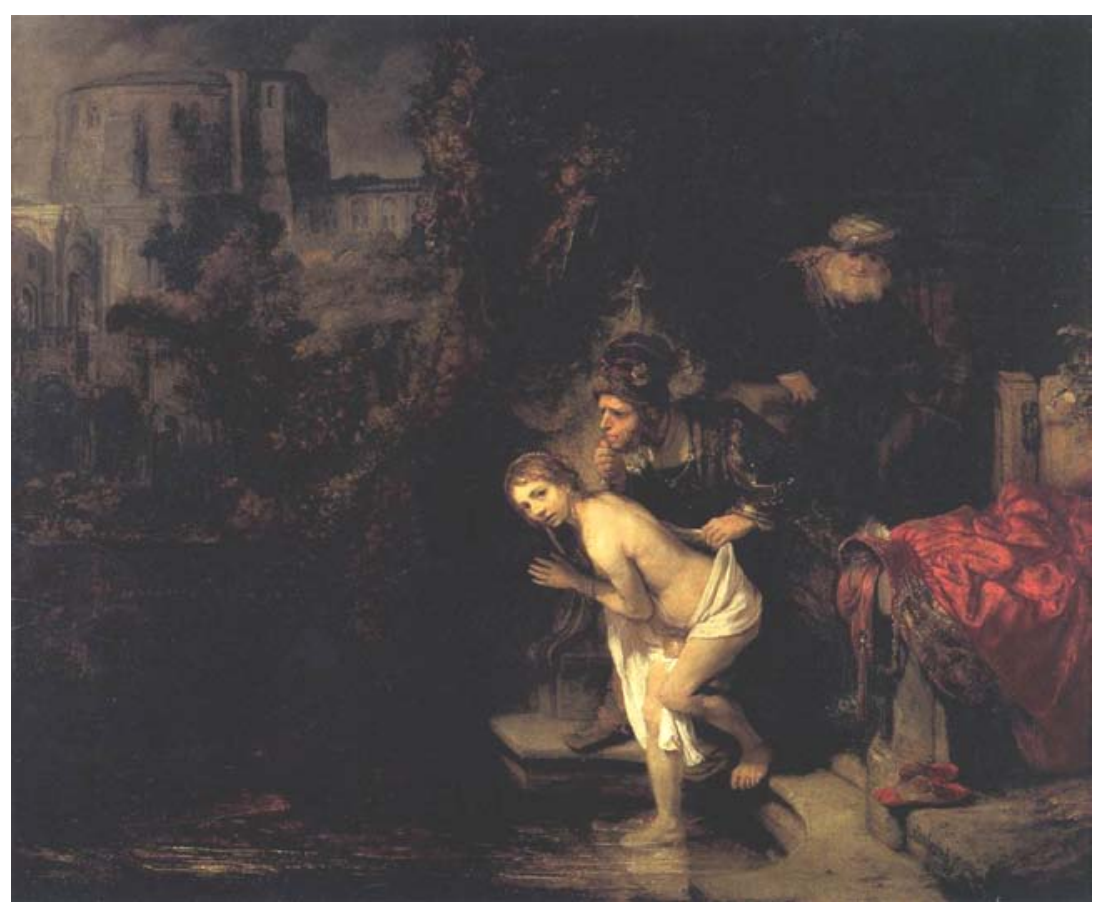

Fonte: Rembrandt (1647).

O olhar comparece como pura violação. Susana é penetrada pelos olhos que a desnudam, tocam sua pele e pretendem macular a açucena ou o lírio branco. 0 fato de que são dois os velhos da história, multiplica a intensidade desse ato voyeurista. Quatro olhos, um plus escópico, ou "um olhar a mais"5.

Entre o sujeito e o Outro, lugar de onde parte o olhar, não há barreiras; os muros são transparentes, tudo o que lhe acontece é observado. As roupas não escondem a nudez diante do olhar do Outro. A visibilidade é total; o Outro vê através das paredes, da roupa, da pele e chega a ler os pensamentos. [...] Na psicose, a Coisa olha. (QUINET, 2002, p. 57).

Em nenhum outro relato bíblico, o tema da pulsão escópica foi tão bem encenado como em Susana e os velhos. E, nunca, foi tão dramaticamente representado como na pintura, principalmente, no período compreendido entre o Maneirismo e o Barroco, durante todo o século XVII. A arte daquele momento consegue uma singular harmonia entre movimento e repouso, entre visível e invisível, entre claro e escuro, entre limitado e ilimitado. Seguindo a Trías (2006), esta arte sempre está dizendo que o presente está

\footnotetext{
${ }^{5}$ Expressão cunhada por Quinet (2002, p. 41) para definir um olhar que, na psicanálise, “[...] não é um olhar do sujeito e sim um olhar que incide sobre o sujeito, é um olhar que o visa: olhar inapreensível, invisível, pulsional.”.
} 
Diálogos entre a pintura e o cinema: análise de representações pictóricas do relato de Susana e os velhos e de sua aparição em Psicose,

invadido e envolvido pelo invisível, e o finito, por um torvelinho de infinitude. "Por isto esta arte pode captar ou 'surpreender' instantâneas fugazes, cenas 'realistas', atos colhidos de surpresa, cenários extraídos do curso mesmo da vida." (TRÍAS, 2006, p. 80, tradução nossa). Atrevemo-nos a dizer que os quadros escolhidos são quase fotogramas, instantâneas fílmicas, convocando-nos a estabelecer um diálogo entre o cinema e a pintura (Figura 11).

Figura 11 - Susana e os velhos, de Peter Paul Rubens, 1607-08.

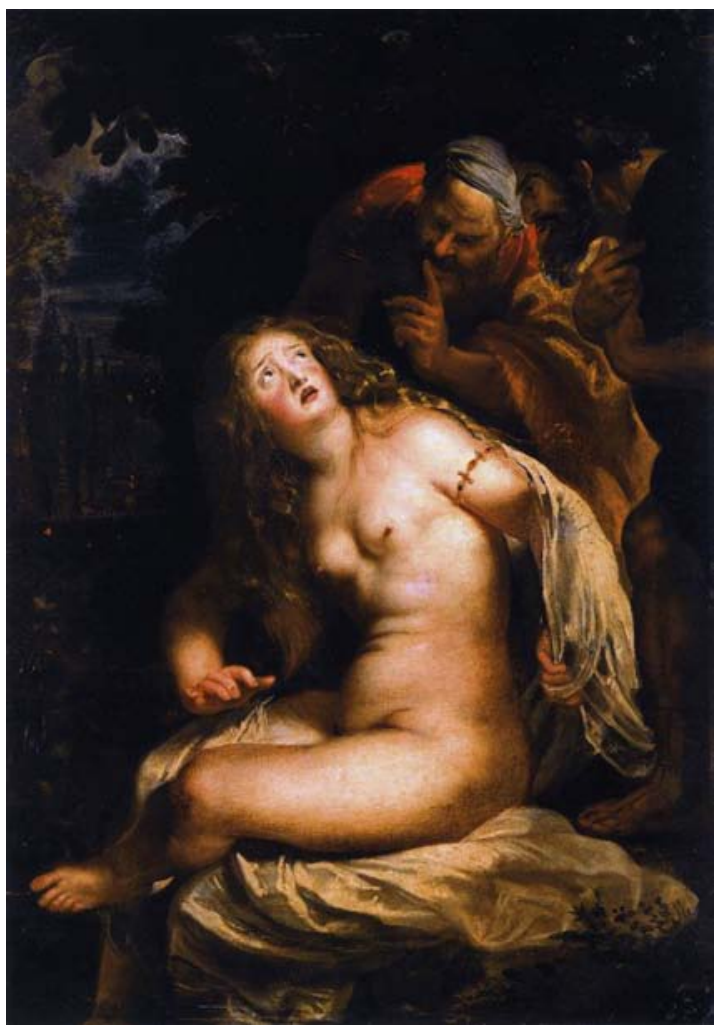

Fonte: Rubens (1607).

A angústia e o desespero de Susana surpreendida no seu momento de intimidade diante da aparição dos voyeurs e sua tentativa de violação foram representados com maestria por pintores como Badalocchio, Lastman, Van Dyck, Rembrandt, Artemisia Gentileschi e Rubens, entre outros. 0 tema, sem dúvida, é fascinante para os artistas graças à tensão que emana do relato bíblico. Sob a batuta de pincéis renomados, o corpo de Susana ganha voz, se expressa com gestos e reafirma sua honra, enquanto os velhos lhe pedem que se cale, sussurram e conspiram (Figura 12). 
Diálogos entre a pintura e o cinema: análise de representações pictóricas do relato de Susana e os velhos e de sua aparição em Psicose,

Figura 12 - Susana e os velhos, de Sir Anthony van Dyck,1621-22,

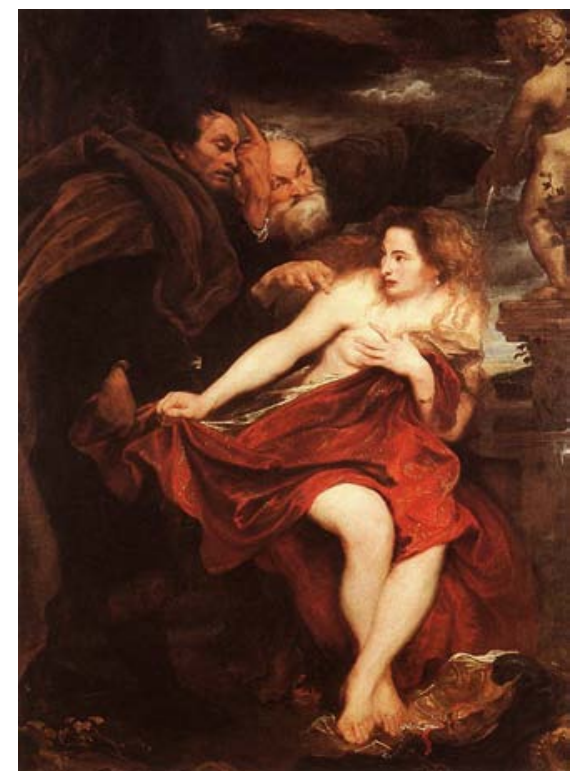

Fonte: Dyck (1621).

Os gestos das mãos masculinas anunciam a calúnia e projetam-se sobre o corpo feminino como garras de ave de rapina que atacam sua presa. Retiram os véus que a cobrem, puxam o manto que oculta o corpo de Susana, querem ver tudo, ver o que não se deve (Figura 13).

A mulher tenta preservar-se e debate-se, protegendo-se com os tecidos que lhe restam, gesticula com suas mãos e mostra seu repúdio com a inclinação de seu corpo. Susana representa este ponto que é fronteira para o olhar, o lugar da mulher como sagrado e inviolável.

Figura 13 - Susana e os velhos, de Peter Paul Rubens, 1609-10 e Susana e os velhos, de Rubens, 1611.
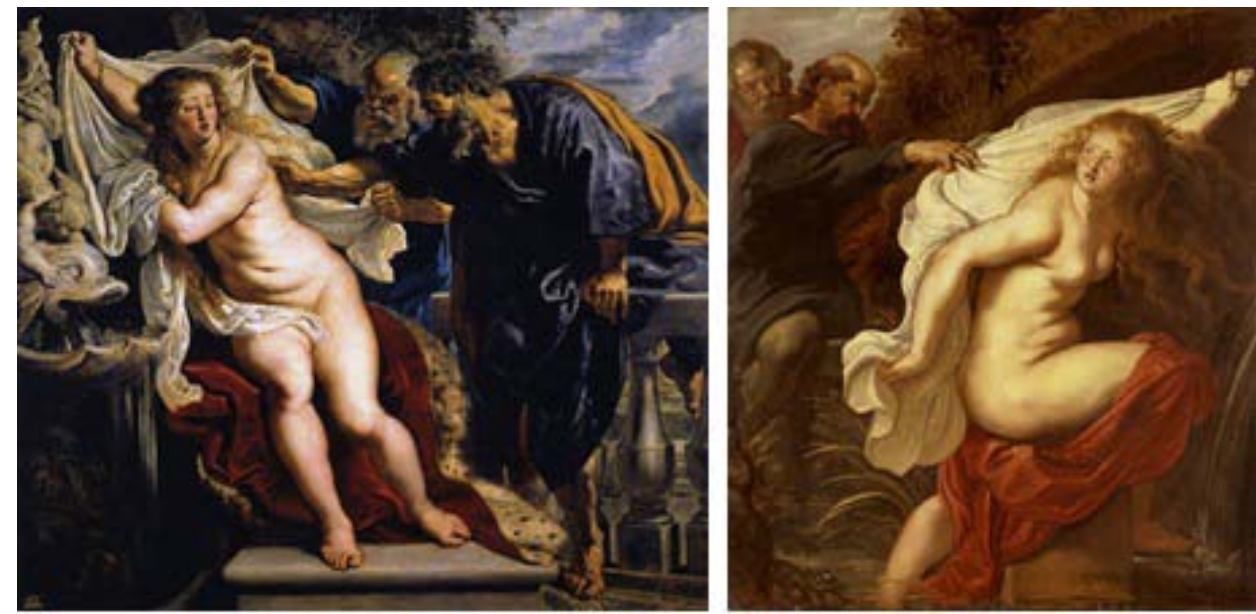

Fontes: Rubens (1609) e Rubens (1611). 
Diálogos entre a pintura e o cinema: análise de representações pictóricas do relato de Susana e os velhos e de sua aparição em Psicose,

Rubens, ao longo de sua vida, representou várias Susanas em luta contra os agressores. Os quadros descrevem um combate corpo a corpo, nos quais os tecidos transformam-se em asas para que a mulher possa fugir dali, longe do alcance das aves de rapina.

No tema representado pela pintora Artemisia Gentileschi (Figura 14), as mãos dos três personagens presentes na cena encontram-se na forma de um expressivo diálogo de assédio e defesa.

Figura 14 - Susana e os velhos - Artemisia Gentileschi, 1610.

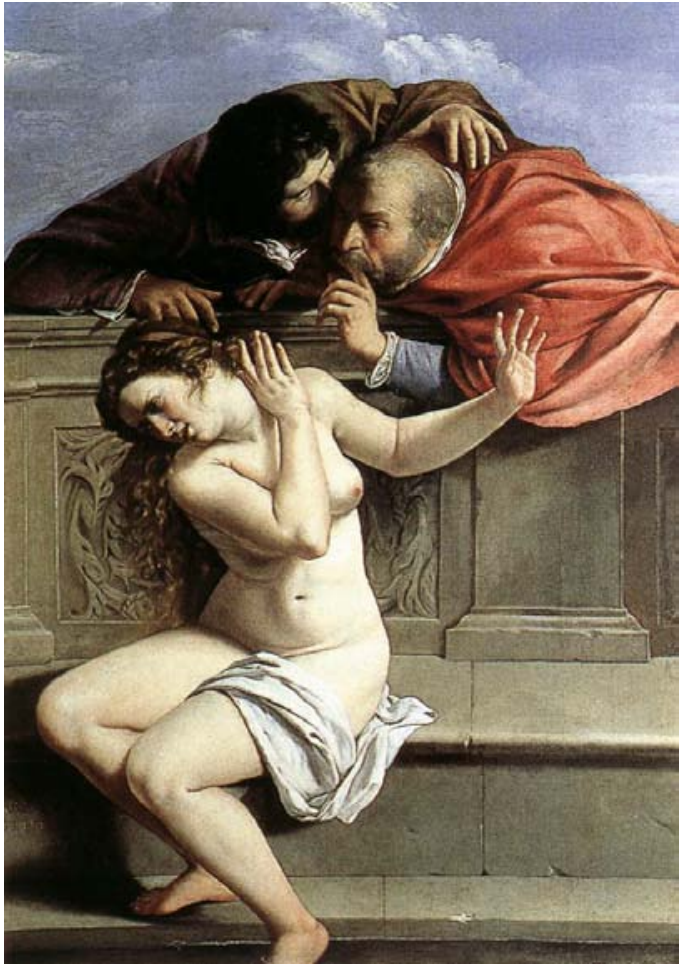

Fonte: Gentileschi (1610).

Na tela de Van Honthorst, as mãos dos velhos juízes contraem-se para tirar o manto feminino, forçam e atacam. As mãos femininas mostram-se desesperadas, crispadas e transformam-se na última arma para proteger aquilo que não deve ser visto nem profanado pelos homens.

Susana, assim como Marion em Psicose, aparece como objeto para ser sacrificado. Nas pinturas barrocas e maneiristas, o corpo branco, erótico, pronto para o olhar fica materializado neste instante em que a mulher percebe que está sendo observada, profanada. Não faltam exemplos de obras que mostram o momento em que Susana nota o olhar de 
Diálogos entre a pintura e o cinema: análise de representações pictóricas do relato de Susana e os velhos e de sua aparição em Psicose,

desejo dos velhos; esse instante fugaz em que tenta proteger-se. A cena representa a virtude contra a infâmia. A mulher estava em seu jardim, desfrutando dos prazeres de seu banho e, de repente, o véu é arrancado, a cortina se abre, e ela se sente observada. É um olhar que fere, que desgarra, como a faca da senhora Bates na cena crucial de Psicose (Figura 15).

Na cena do chuveiro, Marion é cortada, diante dos olhos ávidos do espectador, de diversas maneiras. A começar pela planificação da sequência nos inúmeros cortes, pois há uma extrema associação entre o olho do diretor e a lente da câmera que filma a mulher. As linhas diagonais desenhadas pelos jatos d'água que saem do chuveiro aparecem em contraposição aos movimentos, também diagonais, dos golpes desferidos pela faca. Assim, a sucessão de linhas que se cruzam no espaço ajuda a cortar a mulher, como as próprias facadas da sombra assassina. Os sons agudos dos violinos da trilha sonora de Bernard Hermann completam a sequência de cortes e são a metáfora sonora mais potente para o gesto de sulcar a carne da mulher.

Figura 15 - Cenas Psicose
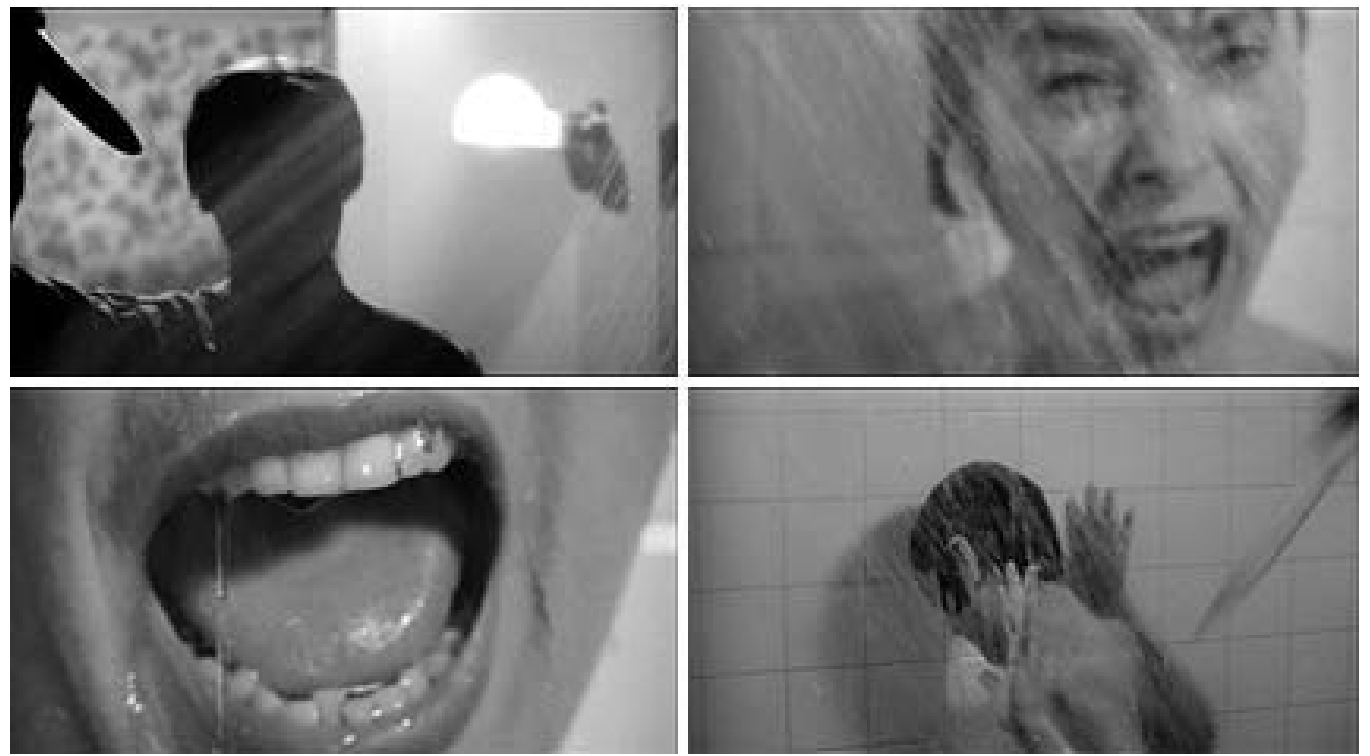

Fonte: Fotogramas capturados pela autora, adaptado de Piscose (1960b).

Observam-se semelhanças impressionantes entre os quadros que encenam o relato de Susana e os velhos e a cena do banheiro de Psicose. 0 trabalho de pesquisa buscou aqueles fragmentos entre os quadros que abordam o tema e os fotogramas do filme para estabelecer este diálogo estético, estrutural e de sentido entre eles. 
Diálogos entre a pintura e o cinema: análise de representações pictóricas do relato de Susana e os velhos e de sua aparição em Psicose,

Figura 16 - Marion grita e defende-se da assassina, e detalhe da pintura de Gerrit van Honthorst
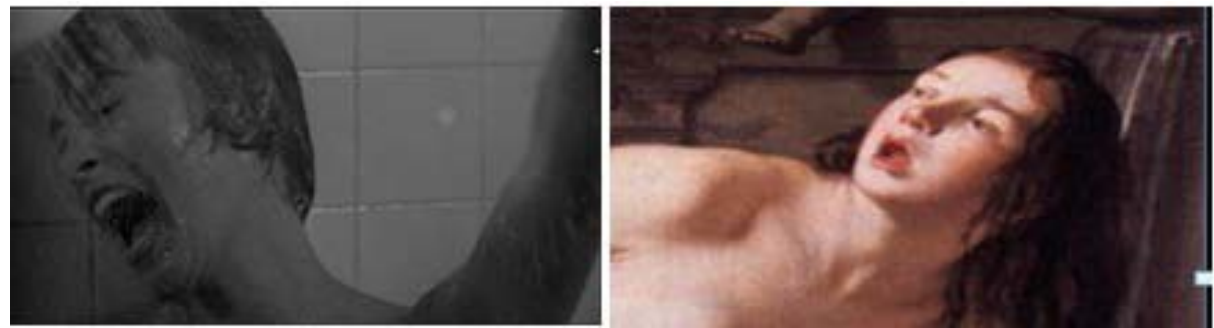

Fonte: Fotograma e detalhe da pintura capturados pela autora e adaptados de Psicose (1960b) e Honthorst (16--?).

0 momento da surpresa, em ambos os relatos, é acompanhado do horror. A boca da mulher se abre em um grito de repúdio ou, como vemos na tela de Van Honthorst (Figura 16), da Galeria Borghese, mostra-se como puro alarido. Ela se contorce, tenta fugir, mas não consegue. $\mathrm{O}$ instante de terror materializa-se. Os velhos juízes negaram a lei que deveriam representar. A moça se assusta, já que eles deveriam protegê-la, ampará-la e não o contrário. A boca aberta ressalta o momento de transição entre o choque e o horror. Este grito que ecoa, no mais íntimo do espectador que observa a pintura, encontra uma rima plástica nos gritos de Marion Crane (Figura 15) segundos depois de abrir a cortina e perceber a silhueta da Sra. Bates ameaçando-a com a faca.

Os acordes agudos dos violinos que se confundem com os gritos de Marion podem ser percebidos também nesse quadro (Figura 16). Tonalidades visuais e sonoras são parte de uma mesma unidade nestas representações que nos ocupam. É interessante ressaltar que o rosto de Susana está, também, em contato com os fios d'agua da cascata da fonte, assim como o de Marion está com os jatos do chuveiro no seu instante final.

Da mesma forma que a mulher do quadro tenta desesperadamente agarrar-se nos panos para proteger-se, Marion agarra-se com força na cortina do chuveiro. Os tecidos e a cortinas são o último ponto de apoio e recurso dessas mulheres a fim de se protegerem (Figura 17).

Figura 17 - Detalhes da pintura Gerrit van Honthorst, e mão de Marion agarrando-se na cortina do banheiro
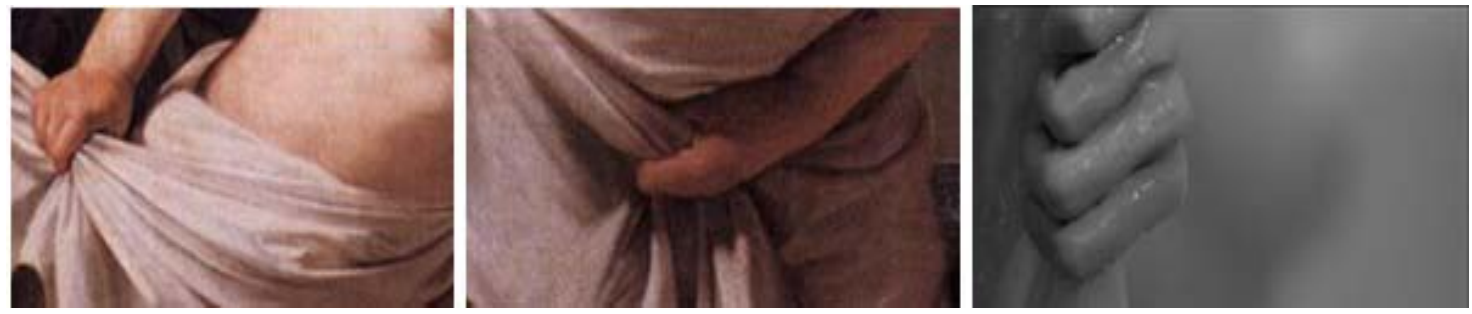

Fonte: Adaptados de Honthorst (16--?) e Psicose (1960b). 
Diálogos entre a pintura e o cinema: análise de representações pictóricas do relato de Susana e os velhos e de sua aparição em Psicose, de Alfred Hitchcock

Este gesto de mãos crispadas tentando, com angústia, agarrar-se em alguma coisa, quando as mulheres estão cara a cara com o Real, é uma constante na maioria dos quadros aqui apresentados. Na Susana de Rubens, da Real Academia de Belas Artes San Fernando e na Susana que está no Museu Hermitage, em São Petersburgo (Figura 18).

Figura 18 - Detalhe das pinturas de Rubens, 1609-10, e 1611
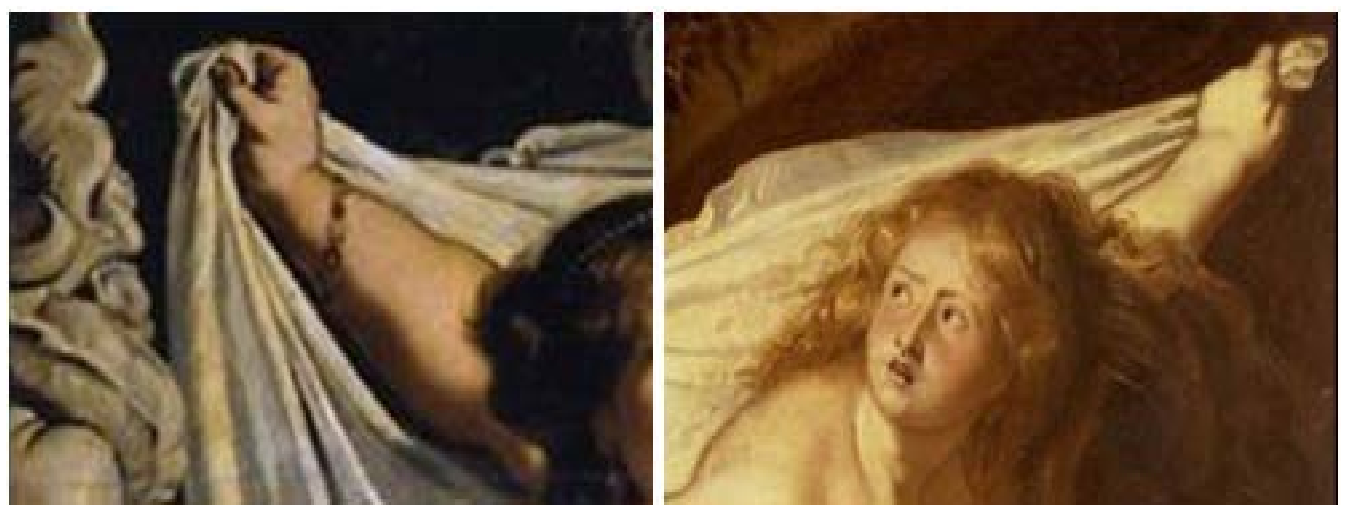

Fonte: Adaptado de Rubens (1609) e (1611).

E ainda, na Susana da galeria Borghese, em Roma (Figuras 11 e 19), bem como na Susana de Van Dyck (Figuras 12 e 19).

Figura 19 - Detalhe pintura de Rubens, 1607-08, e Sir Anthony van Dyck, 1621-22
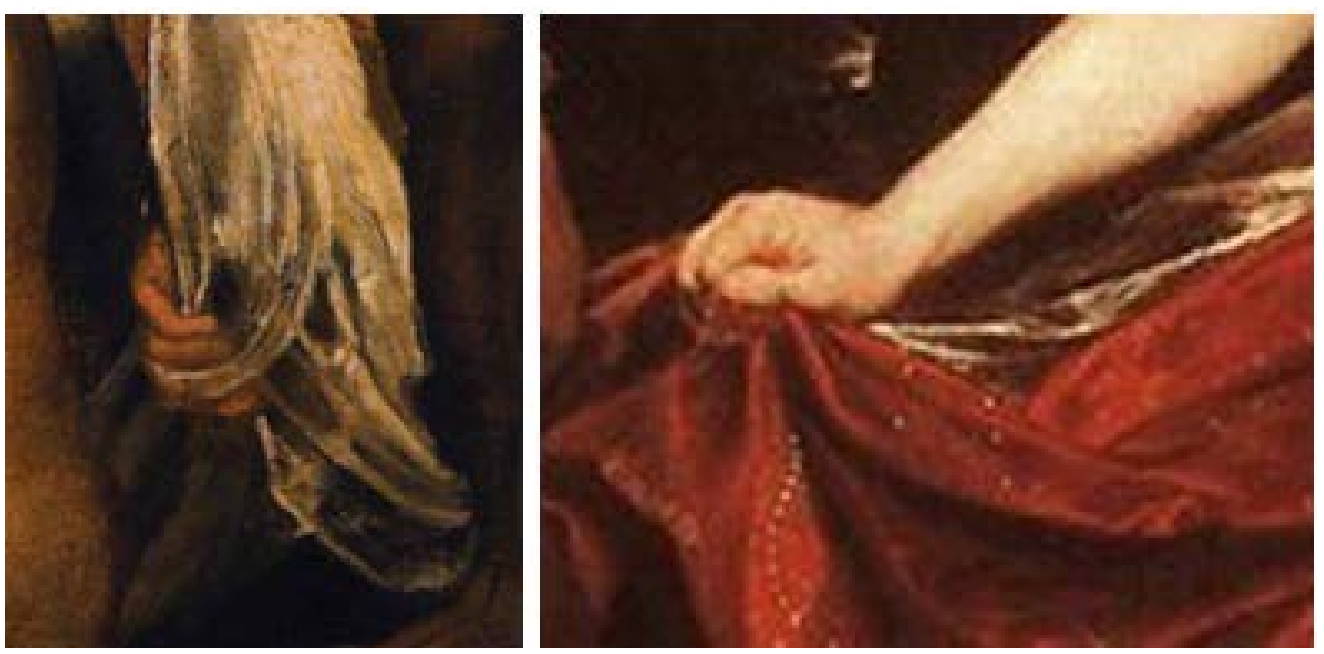

Fonte: Adaptado de Rubens (1607) e Dyck (1621).

Outros gestos que se repetem são os de cobrir os seios com as mãos, uma referência à castidade contra a violação dos velhos. É possível observá-los na Susana de Badalocchio 
Diálogos entre a pintura e o cinema: análise de representações pictóricas do relato de Susana e os velhos e de sua aparição em Psicose,

(Figuras 09 e 20) e na de Van Dyck (Figuras 12 e 20). 0 gesto expressa, também, proteção ao corpo e repúdio à investida dos juízes.

Figura 20 - Detalhe de Sisto Badalocchio, 1609, e Sir Anthony van Dyck,1621-22
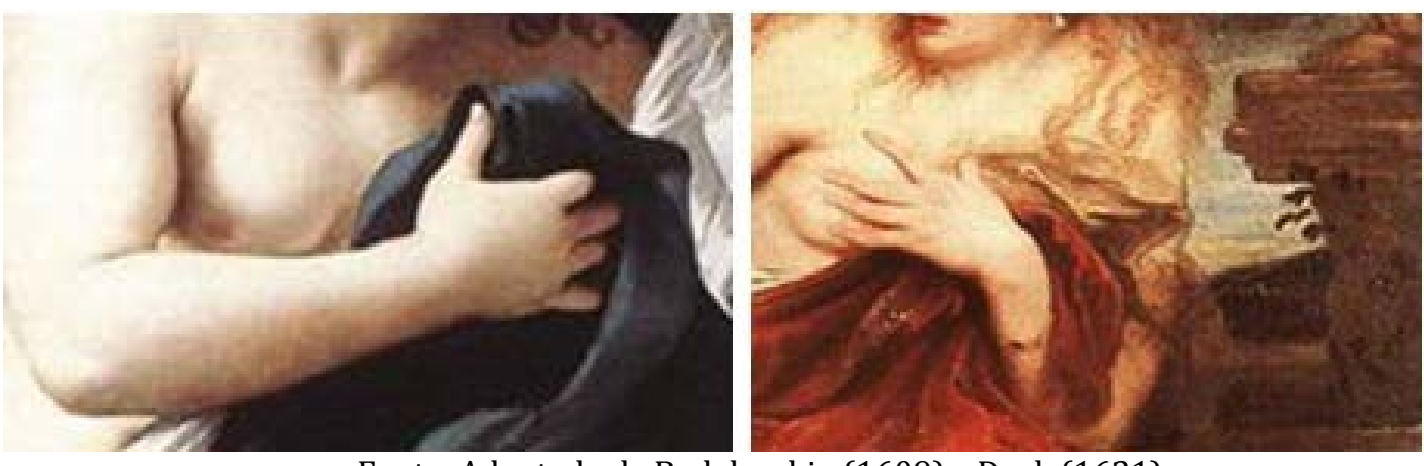

Fonte: Adaptado de Badalocchio (1609) e Dyck (1621).

Ou na de Rembrandt (Figuras 10 e 21). E na de Artemisia Gentileschi (Figuras 14 e 21).

Figura 21 - Detalhe da pintura de Rembrandt, 1647 e Artemisia Gentileschi, 1610
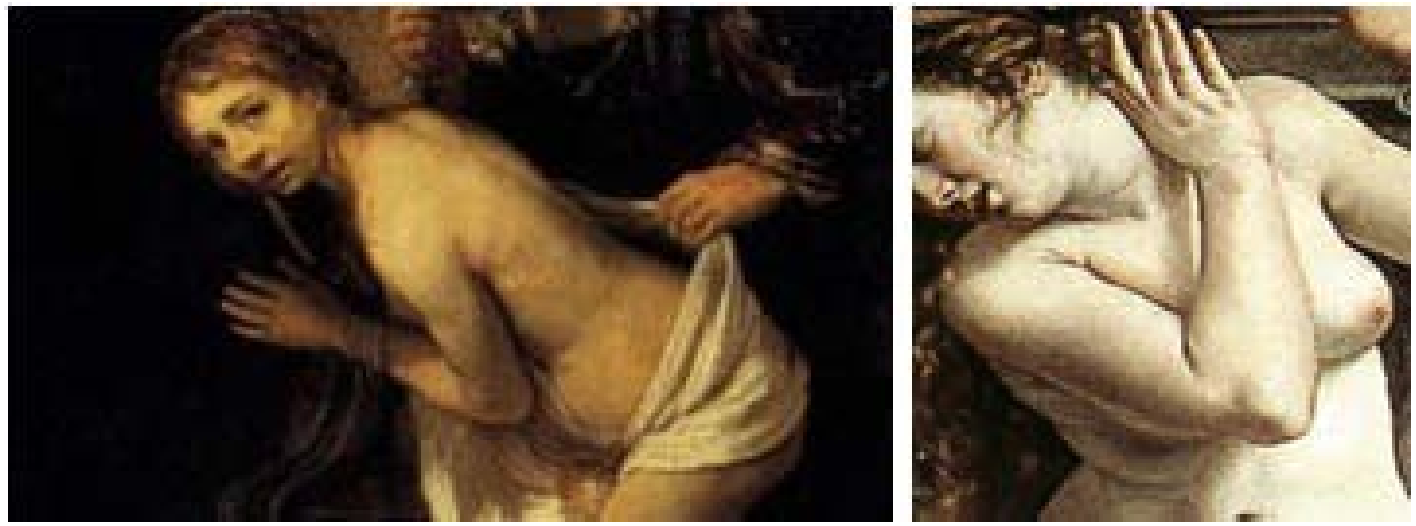

Fonte: Adaptado de Rembrandt (1647) e Gentileschi (1610).

Seguindo os rastros desse gesto, encontrou-se, também, na cena da ducha, uma postura similar de braços e mãos de Marion frente ao ataque da Sra. Bates (Figura 22).

No relato de Susana, o peso do olhar dos velhos juízes tem o valor de facada, visto que fere, penetra na carne, deflora. Susana tenta desviar-se do olhar penetrante dos anciãos com gestos de repúdio, assim como Marion o faz das facadas na cena do chuveiro. 
Diálogos entre a pintura e o cinema: análise de representações pictóricas do relato de Susana e os velhos e de sua aparição em Psicose,

Figura 22 - Cenas do ataque de Marion em Psicose (1960a)
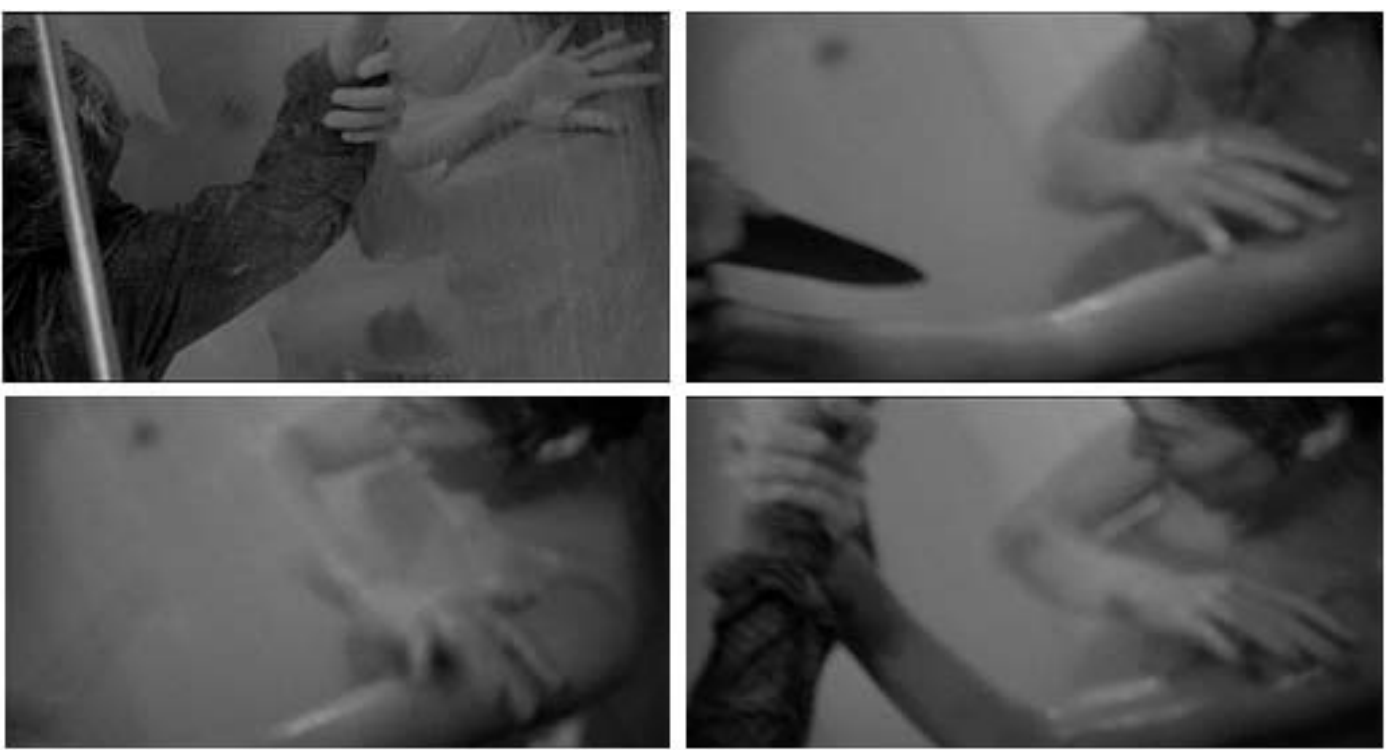

Fonte: Fotograma capturado pela autora, adaptado de Psicose (1960a).

Muito além das referências mostradas e assinaladas nos múltiplos gestos ou enquadramentos quase idênticos da cena do chuveiro de Psicose e as representações de Susana na pintura, as aproximações entre o filme e as telas estudadas são principalmente estruturais. A angústia, o olhar para o corpo feminino, os jogos de oposição entre os gestos do violador e da violada, entre o limitado e o que ultrapassa os limites estabelecidos, entre a borda e o que transborda, todos esses são elementos comuns. Em suma, o fílmico absorve o universo pictórico e esse, por sua vez, revela-se como um fragmento da imagem fílmica: um fotograma (Figura 2). Desta maneira, o quadro que tapa o buraco revela-se em todo o seu sentido.

O buraco na parede que o quadro escondia e que serve à medida para o olho ávido do rapaz vai encontrar uma rima perfeita com aquele outro, o buraco do deságue da banheira por onde escoam o sangue e toda a vida de Marion. Buraco este que se funde com o olho sem vida da mulher, após todas as tentativas fracassadas para salvar-se do predador. No filme Psicose, nada nem ninguém protege Marion, nenhum herói surge para ampará-la. Ao contrario do relato bíblico que tem como clímax o julgamento dos caluniadores, quando Daniel incorpora a lei e demonstra a inocência de Susana, em Psicose, a lei não triunfa no final, só resta um grande buraco negro (Figura 23). 
Diálogos entre a pintura e o cinema: análise de representações pictóricas do relato de Susana e os velhos e de sua aparição em Psicose, de Alfred Hitchcock

Figura 23 - Buraco do desague da banheira, e fusão com olho de Marion
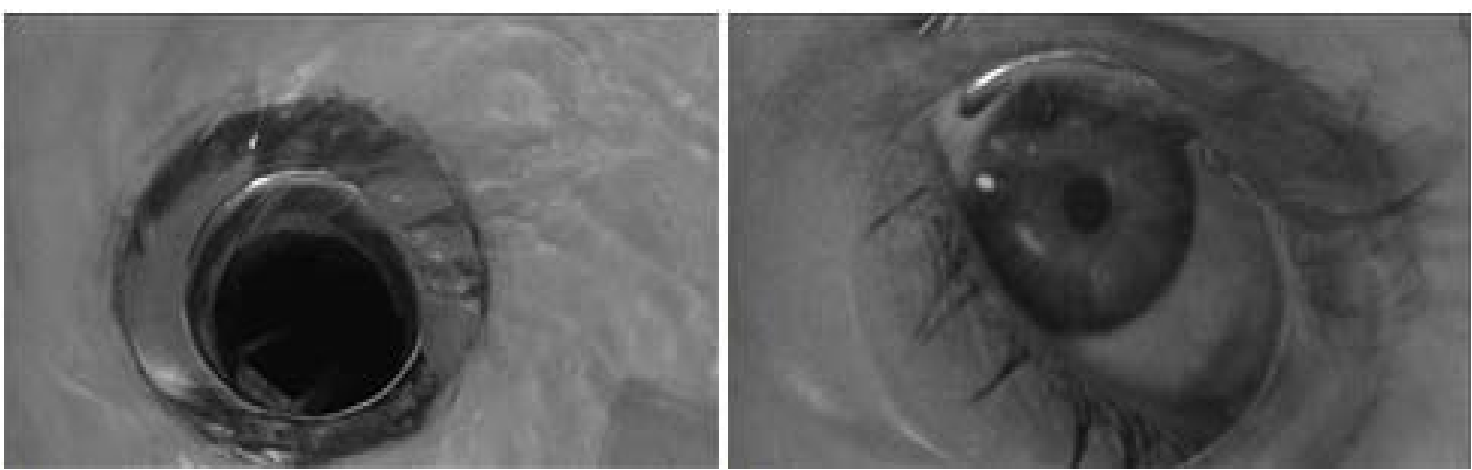

Fonte: Fotograma capturado pela autora, adaptado de Psicose (1960a).

\section{Hitchcock: um olhar que atravessa}

Hitchcock assina os títulos de crédito no início (Figura 24) e no final deles, quando as letras fragmentadas de seu nome vão surgindo atrás de linhas cinzas horizontais.

Figura 24 - Linhas horizontais atravessam o nome de A. Hitchcock

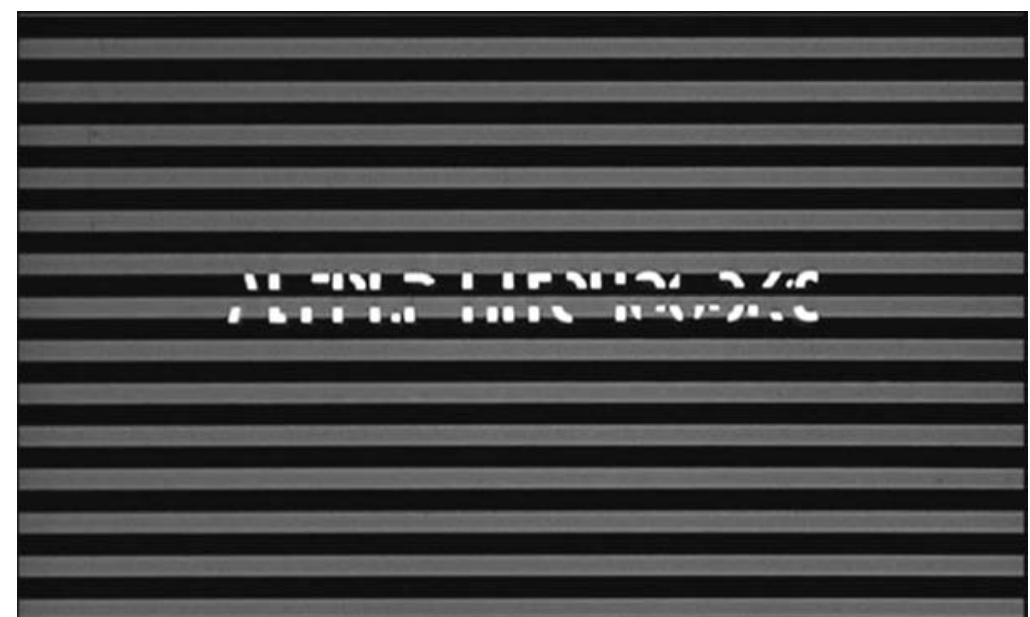

Fonte: Fotograma capturado pela autora, adaptado de Psicose (1960a).

Ele deixa sua marca no nome escrito ao iniciar e fechar os créditos da ficha técnica. Contudo, o cineasta faz questão, também, de aparecer em cena, como em muitos de seus filmes, como uma assinatura visual. 0 momento em que aparece em Psicose é justamente na cena em que observa Marion passar na porta da imobiliária, com um olhar de rapina (Figura 25). A protagonista desse filme está destinada a ser violada visualmente, espiada por olhos masculinos que, tal como os juízes de Susana, burlam e negam a lei que deveriam encarnar. 
Diálogos entre a pintura e o cinema: análise de representações pictóricas do relato de Susana e os velhos e de sua aparição em Psicose,

Figura 25 - Hitchcock observando Marion

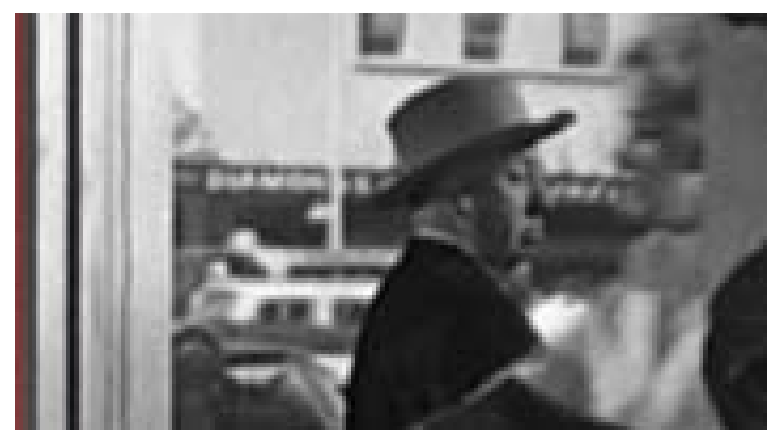

Fonte: Fotograma capturado pela autor, adaptado de Psicose (1960a).

0 diretor assume os mesmos gestos e porte que o Sr. Cassidy (Frank Albertson). Uma cena vem imediatamente após a outra, unindo-as e colocando os dois homens na mesma posição de predadores no relato fílmico. Os dois velhos, Hitchcock e Sr. Cassidy, comparecem em Psicose como os juízes em Susana, com o mesmo olhar que deflora a imagem da mulher. A associação do olhar desses predadores masculinos com o das aves de rapina, olhar objeto de angústia, é o que observa-se em muitos fotogramas (Figura 26).

Figura 26 - Cenas Sr. Cassidy e Marion
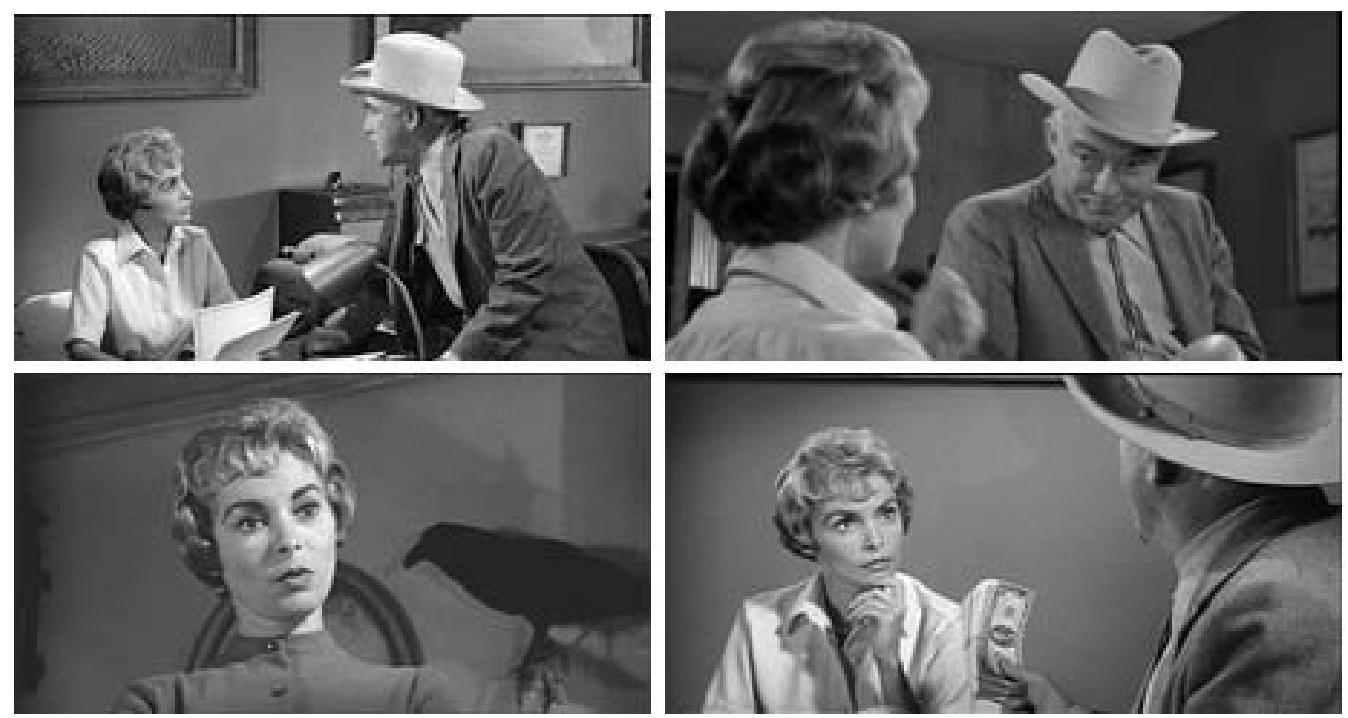

Fonte: Fotogramas capturado pela autora, adaptado de Psicose (1960a).

O olhar do Sr. Cassidy vai se tornando insuportável para a mulher, assim como o dos velhos para Susana, pois é portador de um gozo mortífero, como foi assinalado anteriormente. Na cena da sala dos pássaros empalhados do Motel Bates, Marion foi igualmente observada e ameaçada por um corvo (Figura 26), ave de hábitos necrófagos. 
Diálogos entre a pintura e o cinema: análise de representações pictóricas do relato de Susana e os velhos e de sua aparição em Psicose,

Tratava-se de um plano subjetivo de Norman, um personagem que se revela como a maior e mais ameaçadora de todas as aves predadoras (Figura 27).

Figura 27 - Norman irritado ameaça Marion

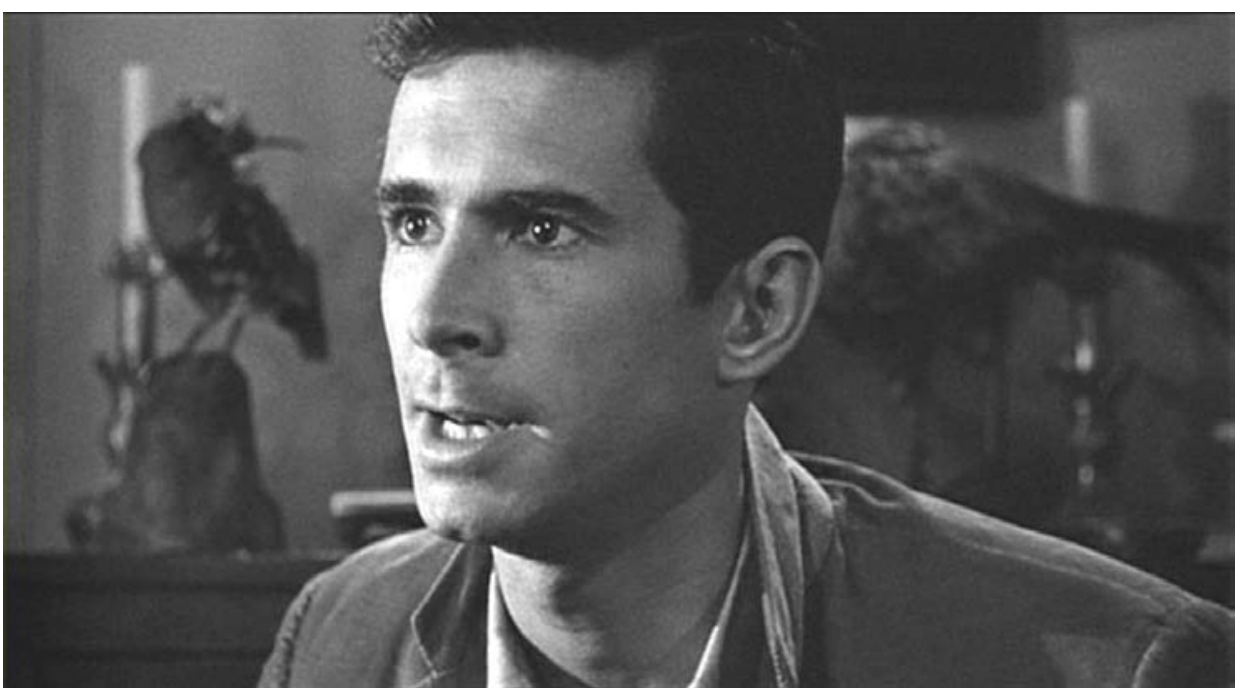

Fonte: Fotograma capturado pela autora, adaptado de Psicose (1960a).

Voltemos à cena do olhar de Norman - olhar que, por sua vez, pode ser análogo ao do espectador e ao do cineasta - quando observa, através do buraco na parede, Marion no seu momento de maior intimidade e quando ela se despe para tomar o banho (Figuras 5).

O olho de Norman está onde o de Hitchcock esteve e onde o do espectador está, ou seja, na mesma posição de predadores em que os velhos no relato de Susana. Marion é mostrada aqui como um pequeno pássaro, em sua gaiola, sendo espiada pela ave de rapina. Assim como nos quadros dos dois passarinhos à direita, a moldura da porta do banheiro a envolve, circunscrevendo-a no retângulo e igualando-a as duas pequenas aves (Figura 5). Neste sentido, ela posiciona-se como um passarinho, uma ave indefesa pronta para ser abatida. Os sons agudos dos violinos, da famosa trilha de Bernard Hermann, rimam esteticamente com o olhar que atravessa e deflora a mulher. A trilha sonora recorda o piado dissonante de uma ave de rapina atacando sua presa.

A violação da lei por quem deveria representá-la permeia todo o filme. Esse aspecto, que é sublinhando insistentemente, vai sendo enfatizado desde a sequência inicial do filme, pelo próprio movimento de câmera em direção à janela do quarto do hotel, onde Marion se encontrava às escondidas com Sam (John Gavin). A câmera espia o corpo da mulher 
Diálogos entre a pintura e o cinema: análise de representações pictóricas do relato de Susana e os velhos e de sua aparição em Psicose,

estendido sobre a cama, uma mirada que viola visualmente, assim como os velhos fazem com a bela Susana.

Durante a fuga da protagonista, após o roubo do dinheiro, Marion estaciona o carro para descansar e, depois de um dia viajando, ela acaba por adormecer profundamente. É despertada pela presença de um policial rodoviário que a interroga. A mulher está indefesa, só, no imenso deserto do Arizona, assim como já assinalava o grande quadro situado atrás de sua mesa no local de trabalho (Figura 28).

Figura 28 - Cenas da Fuga de Marion em Psicose (1960a)
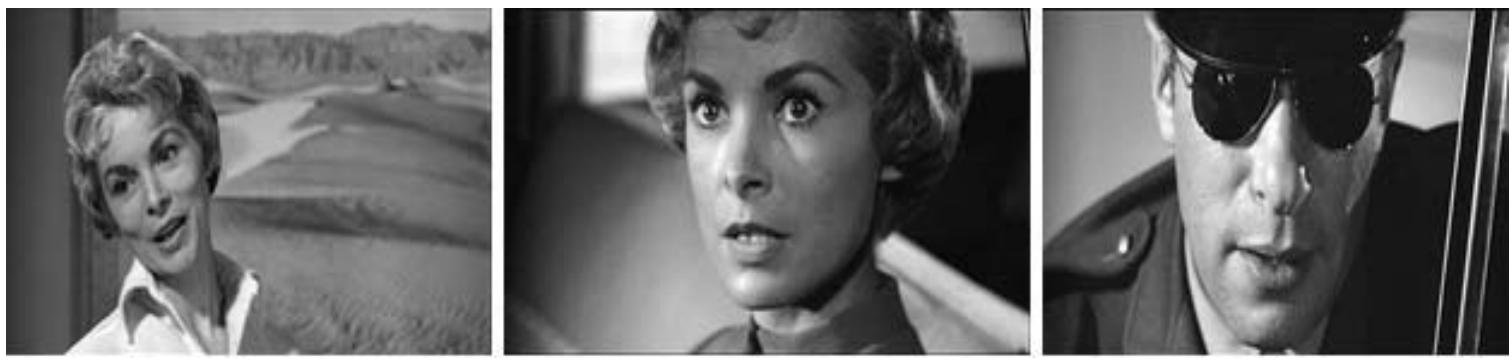

Fonte: Fotograma capturado pela autora, adaptado de Psicose (1960a).

Hitchcock nomeia como nenhum outro diretor a questão do olhar, da insaciabilidade da mirada, do olho como órgão desejante. A começar pelos grandes olhos da protagonista: enormes, grudados na estrada, quase nunca piscam e só se fecham para dormir. Na sequência do encontro com o patrulheiro rodoviário (Mort Mills) na estrada, quando é surpreendida após passar a noite no carro, observam-se os olhos arregalados e expressivos de Marion, em contraste com as duas elipses negras das lentes dos óculos do policial, que ocultam sua potente mirada (RODRÍGUEZ, 2014).

A cena mostra, magnificamente, a oposição construída em um plano com a presença do olhar na mulher e, no contraplano, com um olhar masculino cuja potência não pode ser revelada em imagens. Os impenetráveis óculos escuros surgem em cena para ocultar o insuportável olhar que atravessa. As duas grandes superfícies negras e arredondadas remetem aos dois grandes buracos negros, também no lugar dos olhos, da caveira/mãe revelada no final do filme. A lei ${ }^{6}$ nesse filme não representa nada, e sua ausência está assinalada pela metáfora do buraco negro.

\footnotetext{
${ }^{6}$ A Lei, dentro do marco que trabalhamos, aproxima-se da teoria lacaniana, quando esta se refere ao pai, como portador da lei. Trata-se de uma entidade essencialmente simbólica, ordenadora de uma função que estrutura nossa ordenação psíquica como sujeitos. 0 aparecimento do terceiro elemento na relação dual, a irrupção de Um pai ("Un père", nas palavras de Lacan), é a saída para a crise do sujeito. Ordena, pois é Lei, e possibilita o acesso ao simbólico.
} 
Diálogos entre a pintura e o cinema: análise de representações pictóricas do relato de Susana e os velhos e de sua aparição em Psicose,

Para acentuar esse aspecto de negação da lei, o guarda rodoviário pergunta à moça se ela não acharia melhor hospedar-se em algum motel do que ficar dormindo na estrada. "Por segurança", enfatiza. A ideia acatada, mais tarde, por Marion, conduzirá a moça ao seu final trágico. Ela pergunta, ainda, se infringiu alguma lei, ao que ele lhe contesta que não. 0 guarda não toma nenhuma atitude para impedir que Marion siga seu destino, mas segue seu carro, intimidando-a (Figura 29).

Figura 29 - Fuga de Marion em Psicose (1960a)
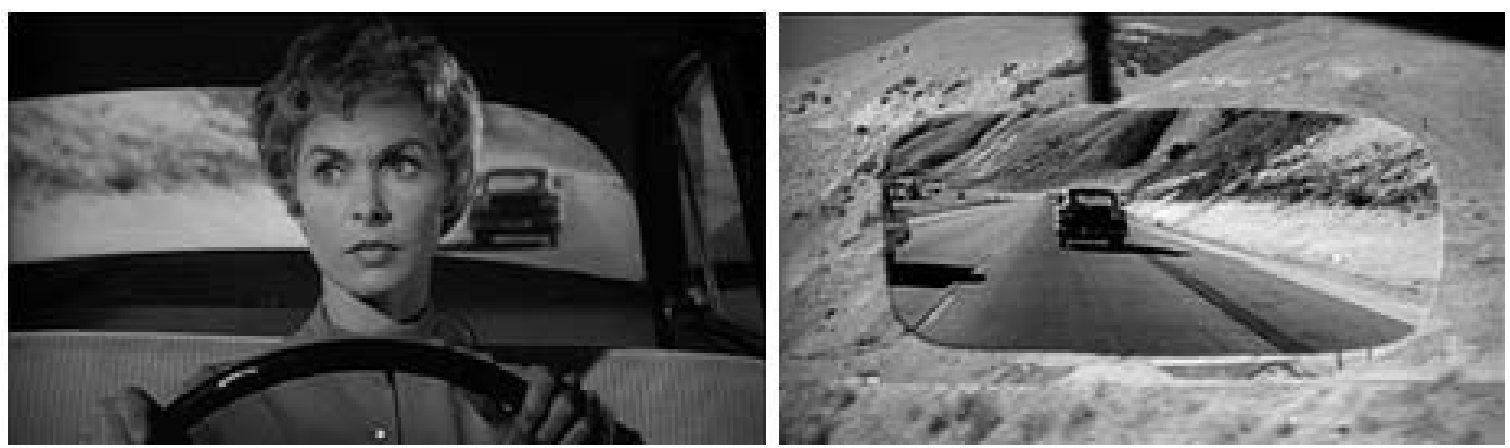

Fonte: Fotograma capturado pela autora, adaptado de Psicose (1960a).

Formalmente e estruturalmente, a escritura fílmica mostra como o simbólico na trama manifesta-se como uma pura ausência: os elementos que deveriam representar a Lei não representam e não encarnam. Todos os personagens que poderiam encarná-la, a transgridem, simplesmente desaparecem do relato sem qualquer gesto heroico, ou são eliminados. Além dos personagens já sublinhados até agora, será assim com o xerife Chambers (John McIntire) ou Milton Arbogast (Martin Balsam), o detetive particular. No entanto, condensando todos eles em um só revela-se a figura do diretor Alfred Hitchcock.

O relato bíblico de Susana culmina com a vitória da lei e a absolvição de Susana que se livra de uma morte por lapidação, graças à intervenção de Daniel, representante de uma lei maior, incorrupta, de uma palavra verdadeira. Susana e os velhos é, portanto, um relato no qual prevalece a lei e no qual o sujeito se sustenta. O contrário ocorre no filme Psicose, de Hitchcock. 0 filme mostra uma fratura do relato, aponta para um lugar vazio, para a emergência do sinistro (do estranho, no sentido freudiano do termo) na pós-modernidade. Contudo, a presença reveladora desse quadro no filme parece indicar que só existe uma maneira possível de enfrentar o terrível buraco negro do real, e é por meio de textos simbólicos. Só um relato torna possível que o sujeito não se perca no abismo, nem nas armadilhas do imaginário. Mostra que existe algo que vai muito além do olhar, e é a visão. 
Diálogos entre a pintura e o cinema: análise de representações pictóricas do relato de Susana e os velhos e de sua aparição em Psicose,

A visão, oposta ao olhar, não pertence ao campo das imagens, já que para operar-se e cristalizar-se não precisa dos olhos, órgãos do olhar. Inclusive, pode-se afirmar que é melhor prescindir deles (RODRÍGUEZ, 2009). Assim, o sentido deste relato que nos interrogou, questionou e mobilizou, representado no quadro que tapa o buraco da sala do Bates Motel, nos conduz aos limites do olhar, demarca certos espaços sagrados e torna possível a prevalência de uma lei justa, isto é, da verdade.

Neste sentido, é significativo o quadro Daniel proclama a inocência de Susana (1625), de Valentin de Boulogne, pertencente ao Museu do Louvre, em Paris. Na pesquisa sobre o tema de Susana e os velhos, esse quadro, cuja cena é protagonizada pelo profeta Daniel, ressaltou-se como uma possível resposta ao enigma inicialmente proposto. Na pintura, observa-se um detalhe significativo: a poltrona sobre a qual Daniel está sentado tem como braço um entalhe com a figura de uma esfinge (animal mitológico que propõe o enigma sobre a condição humana). 0 gesto da mão direita do profeta, tapando os olhos da esfinge, (Figura 30) ressalta que o crime cometido contra Susana foi no âmbito de um olhar portador do gozo mortífero, do voyeurismo, e, por isto, deve ser contido, impedido e limitado. 0 ser humano é um ser de limites e esta é a máxima de sua condição, sem a qual se corre o risco do retorno à barbárie.

Figura 30 - Daniel proclama a inocência de Susana, Valentin de Boulogne (1625), e detalhe da mesma pintura
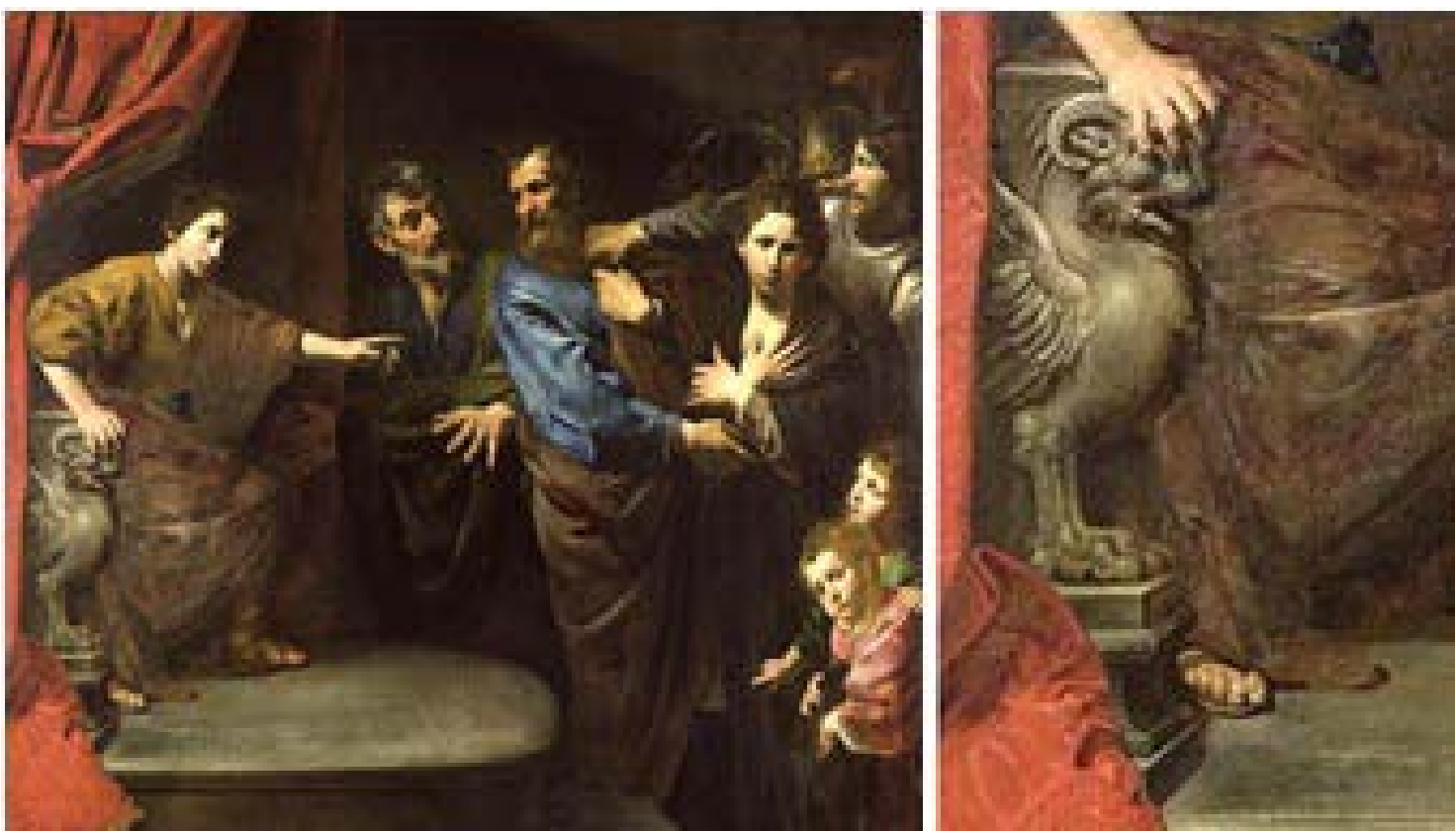

Fonte: Adaptado de Boulogne (1625). 


\section{Considerações finais}

O quadro Susana e os velhos mereceu uma atenção especial nessa pesquisa, porque acredita-se que sua aparição e localização constituem uma parte importante do relato do filme Psicose (1960a), ajudando na construção da história dirigida por Hitchcock. O quadro está localizado em uma saleta, a sala dos pássaros empalhados, e está dependurado ao lado de outras cópias de famosas obras como a Vênus no espelho, de Ticiano e o Banho de Vênus, de François Boucher. Susana é bela como Vênus, mas tem uma sensualidade que encanta pela pureza de seu caráter. Entretanto, não foi uma cena de Vênus a escolhida para tapar o buraco por onde Norman espia sua presa e, sim, a de Susana sendo atacada pelos velhos juízes. No relato bíblico, os anciãos queriam profanar "o belo" da açucena, manchar a beleza que havia atraído poderosamente o seu olhar.

Todo o filme está pontuado por obras de arte. Em quase todas as cenas de Psicose, elas atuam como poderosos significantes que nos conduzem a significados que não só ajudam a delinear o enredo, mas também são fundamentais em sua composição. Em outras palavras, a cena em que Norman observa Marion furtivamente, pelo buraco na parede, não teria a mesma intensidade se não tivesse como ouverture o quadro de Susana e os velhos. A cena interpretada na obra de arte encontra eco na cena do chuveiro de Psicose, e Marion sendo agredida pela Sra. Bates mostra os mesmos gestos de Susana representada nos quadros que abordam o tema, conforme foi assinalado ao longo do artigo.

A representação de Susana é o ponto de partida para uma série de violações que vão anteceder a morte da mulher em Psicose, antecipando o voyeurismo, a violência, a corrupção e a maldade extrema, quando é cometida por alguém que deveria representar e encarnar a lei. Sendo assim, o posterior ataque a Marion ganha maior potência ao ser precedido pelo quadro de Susana sendo atacada. O suspense de Hitchcock funciona como uma bomba relógio prestes a explodir, visto que anuncia ao espectador a violenta cena que vem a seguir. "A bomba está debaixo da mesa e a plateia sabe disto, provavelmente porque viu o anarquista colocá-la. [...] oferecemos quinze minutos de suspense. Donde se conclui que é necessário informar ao público sempre que possível[...]" (TRUFFAUT; SCOTT, 2004, p. 77). 0 espectador sabe que algo está a ponto de ocorrer, algo terrível em Psicose (1960a). Ele viu a silhueta da mulher na janela da mansão dos Bates, os pássaros empalhados em postura de ataque, o discurso de Norman em tom de ameaça e, para culminar, o quadro com a imagem de Susana sendo agarrada pelos juízes e o grande olho devorador. É uma escalada de pequenos signos-bomba que antecipam a grande explosão: a morte da protagonista. 
O quadro em questão não está aí para cumprir somente uma função estética. Ele é também a antessala do sinistro que virá na próxima sequência. Por isto, seguimos os passos de Trías (2006), em sua análise do Nascimento de Vênus, de Botticcelli. 0 autor explica que a beleza de Afrodite é uma aparência e um véu que escamoteia nossa visão de um abismo sem fundo. Ela recobre um buraco ontológico simbolizado por um vazio de um corpo, o de Uranos, do qual foram arrancados os genitais por seu filho Cronos.

Assim como a obra do renascentista, a pesquisa sobre a pintura de Susana e os velhos permite "[...] vislumbrar o que a categoria tradicional de beleza deixa na sombra: o além do limite que ela estabelece, o fundo tenebroso de cujo ocultamento brota a bela aparência [...]" (TRÍAS, 2006, p. 66, tradução nossa). A beleza da representação tapa um buraco disforme, caminho de um olhar que ultrapassa barreiras e que conduzirá a uma morte violenta, como poucas vezes se tinha visto no cinema. A partir deste momento, o sinistro emerge na tela.

Ao analisarmos várias representações pictóricas do século XVII, do conto bíblico de Susana e os velhos, é possível estabelecer um diálogo, uma ordem, pontos de interseção que construíram uma máquina estrutural fundamental para a interpretação de outra obra de arte que é o filme Psicose. Neste sentido, os movimentos de Marion na cena do chuveiro trazem no seu âmago as imagens gestuais presentes nas representações de Susana e os velhos. Tal consideração corrobora com o pensamento de Warburg (19907 apud TEIXEIRA, 2010), em sua teoria sobre a persistência da memória arcaica em obras de arte, isto é, “[...] forças estéticas motivadoras das representações pictóricas e esculturais, numa efetiva pósvida das Pathosformeln antigas [...]" (TEIXEIRA, 2010, p. 140). As imagens e os gestos de Marion Crane, na cena do chuveiro, em Psicose, apresentam camadas extremamente profundas e arraigadas a elementos imagéticos localizados em várias pinturas que abordam o tema de Susana e os velhos, que sobreviveram e que se transportaram através dos séculos e de uma cultura para outra.

O que surgiu, também, no decorrer da pesquisa, foram as referências e os diálogos estéticos entre os protagonistas masculinos que foram assinalados anteriormente e que ocupam, estruturalmente, a mesma posição dos velhos juízes. Tratam-se das figuras masculinas que, devendo encarnar a lei, a ultrajaram, atuando como predadores e corruptos: Norman Bates, o Sr. Cassidy, o guarda rodoviário e o próprio Hitchcock se dirigem à protagonista como um olhar que provoca uma angústia impossível de suportar.

7 WARBURG, Aby. L'art du portrait et la bourgeoisie florentine. Essais florentins. Paris: Klincksieck, 1990. Apud Teixeira (2010, p. 140). 
Diálogos entre a pintura e o cinema: análise de representações pictóricas do relato de Susana e os velhos e de sua aparição em Psicose,

Um olhar que atravessa, que rompe com os limites, os muros e os véus, desvelando o que deveria permanecer velado.

Esses elementos primordiais, potencialidades contidas nas imagens, tocam, comovem, provocam emoções profundas no espectador, através do tempo, da história e das culturas. Formam um núcleo original: instantâneo, mas permanente. Sendo assim, essa é a matériaprima que molda as obras de arte imortais.

\section{Referências}

BADALOCCHIO, Sisto. Susana e os velhos. 1609. Óleo sobre tela. Ringling Museum of Art, Sarasota.

BOULOGNE, Valentin de. Daniel proclama a inocência de Susana. 1625. 1 Óleo sobre tela. BOTH, Jan. Susana e os velhos. 1642. Óleo sobre madeira.

CALABRESE, Omar. Como se lê uma obra de arte. Coimbra: Edições 70, 1997.

DYCK, Sir Anthony van. Susana e os velhos. 1621-22. Óleo sobre tela. Alta Pinacoteca. Munique.

GENTILESCHI, Artemisia. Susana e os velhos. 1610. Óleo sobre tela. Schloss Weissenstein, Pommersfelden.

GONZÁLEZ REQUENA, Jesús. Film, discurso, texto. Hacia una teoría del texto artístico. Revista de Ciencias de la Información, Madrid, n. 2, p. 15-40, 1985.

GONZÁLEZ REQUENA, Jesús. Frente al texto fílmico; el análisis, la lectura. A propósito de El manantial de King Vidor. In: GONZÁLEZ REQUENA, Jesús (Org.) El análisis cinematográfico. Madri: Editorial Complutense, 1995. p. 11-45.

GONZÁLEZ REQUENA, Jesús. El texto: tres registros y una dimensión. Trama y Fondo, Madrid, v. 1, n. 1, p. 03-32, 1996.

GUERCINO. Susana e os velhos. 1617. Óleo sobre tela. Museu do Prado, Madri.

HONTHORST, Gerrit van. Susana e os velhos. [16--?]. Óleo sobre tela. Galeria Borghese, Roma.

MANGUEL, Alberto. Lendo imagens: uma história de amor e ódio. São Paulo: Companhia das Letras, 2001.

MICHAUD, Philippe-Alain. Aby Warburg e a imagem-movimento. Rio de Janeiro: Contraponto, 2013. 
Diálogos entre a pintura e o cinema: análise de representações pictóricas do relato de Susana e os velhos e de sua aparição em Psicose,

MIERIS, Frans van. Susana e os velhos. [16--?]. Óleo sobre madeira. Musée Hyacinthe Rigaud, Perpignan.

QUINET, Antonio. Um olhar a mais: ver e ser visto na psicanálise. Rio de Janeiro: Jorge Zahar, 2002.

PSICOSE. Direção: Alfred Hitchcock. [S. l.]: Paramout Picture, 1960a. 1 DVD (109 min).

PSICOSE [trailer]. Direção: Alfred Hitchcock. [S.l.: s.n.], 1960b. Disponível em:

<http://www.youtube.com/watch?v=CnlCtlSqIjM\&feature=related $>$. Acesso em: 29 maio 2012.

REMBRANDT, Harmenszoon van Rijn. Susana e os velhos. 1647. Óleo sobre madeira. Staatliche Museen, Berlin.

RODRÍGUEZ, Vanessa Brasil. A verdade da palavra mítica uma análise do mito de Édipo. Acta Semiótica et Linguística, João Pessoa, v. 14, n. 2, p. 101-116, 2009.

RODRÍGUEZ, Vanessa Brasil. Além do Espelho: análise de imagens de arte, cinema e publicidade. 2. ed. Curitiba: Appris, 2014.

RUBENS, Peter Paul. Susana e os velhos. 1607. Óleo sobre tela. Galeria Borghese, Roma.

RUBENS, Peter Paul. Susana e os velhos. 1609. Óleo sobre madeira. Museu da Real Academia de Belas Artes de San Fernando. Madri.

RUBENS, Peter Paul. Susana e os velhos. 1611. Óleo sobre madeira. The Hermitage. St. Petersburg.

SAMAIN, Etienne. As "Mnemosyne(s)" de Aby Warburg: entre antropologia, imagens e arte. Revista Poiésis, Florianópolis, n. 17, p. 29-51, Jul. 2011.

TEIXEIRA, Felipe Charbel. Aby Warburg e a Pós-vida das Pathosformeln Antigas. História da Historiografia, Ouro Preto, n. 5, p. 134-147, set., 2010.

TRÍAS, Eugenio. Lo bello y lo Siniestro. Barcelona: Debolsillo, 2006.

TRUFFAUT, François; SCOTT, Helen. Hitchcock/Truffaut: entrevistas. São Paulo: Companhia das Letras, 2004.

WEB GALLERY OF ART. Museu virtual. Budapeste, 1996. Disponível em: <https://www.wga.hu/index1.html>. Acesso em: 27 abr. 2016. 


\title{
Dialogues between painting and cinema: analysis of the pictorial representations of Susanna and the Elders and its appearance in Psycho, by Alfred Hitchcock.
}

\begin{abstract}
The article is the result of a research on the movie Psycho, by Alfred Hitchcock, from 1960. The theme of the picture that covers the hole, through which the protagonist Norman Bates sees Marion Crane undressing is the element of our analysis. This is a representation of the biblical tale of Susanna and the Elders which addresses voyeurism, the incestuous desire of two judges and the violation. The work approaches the semiotic research on interface with psychoanalysis, anthropology and communication in culture. The method discussed is the filmic discourse and pictorial analysis. We mention the formal, aesthetic and structural resonances between the paintings and the film. The images analyzed in Psycho have extremely deep layers and rooted the elements located in several paintings of the 17th century, which address the topic of Susanna and the Elders. The ones that survived moved through time, space and between cultures.
\end{abstract}

\section{Keywords}

Discourse analysis. Cinema. Alfred Hitchcock. Susanna and the elders. Voyeurism.

Recebido em 03/09/2016

Aceito em 20/04/2017 